\title{
Molecular systematics, historical ecology, and phylogeography of Halimeda (Bryopsidales)
}

\author{
Wiebe H.C.F. Kooistra, ${ }^{a, *}$ Eric G.G. Coppejans, ${ }^{b}$ and Claude Payri ${ }^{c}$ \\ ${ }^{a}$ Smithsonian Tropical Research Institute, Box 2072, Balboa, Panama \\ ${ }^{\mathrm{b}}$ Research group Phycology, Botany Department, Ghent University, Krijgslaan 281/58, B-9000 Ghent, Belgium

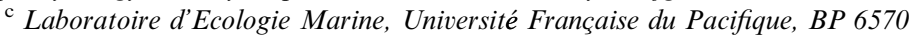 \\ FaaalAeroport, Tahiti, French Polynesia
}

Received 13 September 2001; received in revised form 14 March 2002

\begin{abstract}
Halimeda (Bryopsidales), a genus of calcified, segmented green seaweeds, abounds in reefs and lagoons throughout the tropics. To investigate phylogenetic, phylogeographic, and historic ecological relationships of the genus, the nuclear rDNA including the SSU and both ITS regions were sequenced. A maximum likelihood tree revealed the following: (1) there were anatomical and morphological synapomorphies for five well-supported lineages; (2) the last common ancestor of one lineage invaded sandy substrata; those of two other lineages established in wave-affected habitats, whereas the cenancestor of the remaining two lineages occupied sheltered rocky slopes. Yet, several species adapted to new habitats subsequently, resulting in several cases of convergence; (3) all lineages separated into Atlantic and Indo-Pacific daughters, likely resulting from the rise of the Panamanian Isthmus. Each daughter pair gave rise to additional convergent species in similar habitats in different oceans; (4) Halimeda opuntia, the only monophyletic pantropical species detected so far, dispersed from the Indo-Pacific into the Atlantic well after the closure event; (5) minor SSU-sequence differences across species and phylogeographic patterns of vicariance indicated a relatively recent diversification of the extant diversity. Cretaceous and Early Tertiary fossil look-alikes of modern species must then have resulted from iterative convergence. (c) 2002 Elsevier Science (USA). All rights reserved.
\end{abstract}

Keywords: Calcareous algae; Cognate; Convergence; Dispersal; Fossil; Halimeda; Historical ecology; Iterative evolution; ITS; Phylogeny; Phylogeography; rDNA; Vicariance

\section{Introduction}

The segmented, calcified thalli of the seaweed genus Halimeda (Lamouroux, 1812) are among the most phenotypically complex within the bryopsidalean algae (Vroom et al., 1998). As in other members of this order (sensu Van den Hoek et al., 1995), thalli consist of branched siphons without cross walls, permitting unimpeded migration of protoplasmic components across the thallus superstructure (Drew and Abel, 1990; Littler and Littler, 1999). Segments are composed of an inner medulla and a peripheral cortical layer. Medullary siphons string the segments together or branch

\footnotetext{
${ }^{*}$ Corresponding author. Present address: Stazione Zoologica 'Anton Dohrn', Villa Comunale, 80121 Naples, Italy. Fax: +39-081-7641355. E-mail address: kooistra@alpha.szn.it (W.H.C.F. Kooistra).
}

into the cortex where they rebranch into layers of short, often inflated siphons called utricles. Peripheral utricles, which are always inflated, adhere and enclose the segment's intersiphonal spaces (Barton, 1901). There, calcium carbonate precipitates as aragonite (Borowitzka and Larkum, 1977). Some medullary siphons surface in weakly calcified regions of the segment's distal perimeter where they adhere and may fuse. Their tips can develop new segments (Hay et al., 1988), secondary holdfasts (Hillis-Colinvaux, 1980; Walters and Smith, 1994) or gametangia (Gepp, 1904; Kamura, 1966). Thalli are holocarpic; with the onset of sexual reproduction the protoplasm amasses in gametangia where it is converted into gametes (Meinesz, 1980). The latter are released in concert (Drew and Abel, 1988) in species-specific short intervals (Clifton, 1997; Clifton and Clifton, 1999). 
At present, 33 extant Halimeda species are recognized (Table 1; Ballantine, 1982; Dong and Tseng, 1980; Drew, 1993, 1995; Hillis-Colinvaux, 1980; Noble, 1986). They abound in a range of reef habitats (Gilmartin, 1960; Hillis-Colinvaux, 1980, 1986; Roberts et al., 1987; Taylor, 1950, 1960; Tsuda and Kamura, 1991; Tsuda and Wray, 1977; Van den Hoek et al., 1978). Several morphological traits seem to be linked to particular habitats, e.g., unconsolidated substrata or wave exposed sites (Hillis-Colinvaux, 1980); these traits must have been acquired once or more depending on whether adaptation to these environments occurred once or multiple times.

Although most species are confined to either the tropical Atlantic or the tropical Indo-Pacific (HillisColinvaux, 1980) many have close look-alikes in the other ocean. Their similarity may result from (sub)-recent dispersal. Alternatively, look-alike pairs could result from vicariant events separating the tropical Atlantic from the tropical Indo-Pacific (Coates and Oblando, 1996; Rögl and Steininger, 1984). In the latter case the phenotypically similar species may be nearest neighbors (geminates) or polyphyletic entities (cognates) coming about through convergence.

The empty "ghost"-thalli that are left behind following gamete shedding fall apart in loose segments adding their casts to the sediment (Drew, 1993; Freile et al., 1995; Payri, 1988; Roberts et al., 1987). Therefore, the genus has an extensive fossil record (Badve and Nayak, 1983; Braga et al., 1996; Elliott, 1965; Flügel, 1988; Mankiewicz, 1988) that goes back with certainty to the Early Cretaceous (Bucur, 1994). Many Late Cretaceous and Early Tertiary fossils show similarity to extant groups of species (Morellet and Morellet, 1922, 1941; Schlagintweit and Ebli, 1998) suggesting that the extant diversity consists of living fossils. Alternatively, similar phenotypes may have appeared through iterative evolution (Cifelli, 1969; Newell, 1967).

The issues raised can be addressed by analysis of data that are independent of environmental influence. Many authors have used nuclear rDNA (nrDNA) sequences for phylogenetic inferences in green algae (Bakker et al., 1994, 1995a, 1995b; Coleman and Mai, 1997; Durand et al., 2002; Famà et al., 2000; Jousson et al., 1998; Nakayama et al., 1998; Olsen et al., 1994, 1998). Different mutation rates among nrDNA regions permit phylogenetic resolution at several taxonomic levels (Jorgensen and Cluster, 1988). In their preliminary phylogenetic assays of Halimeda, Hillis et al. (1998) and Kooistra et al. (1999) revealed tentative agreement between sequence phylogenies and changes among some phenotypic characters. However, their trees were inferred from only a part of the SSU nrDNA. In this paper, we surveyed a larger portion of the nrDNA, including the internal transcribed spacer regions (ITS-1 and ITS-2), from a greater number of species in the
Table 1

Described species in Halimeda and their reported distribution

\begin{tabular}{|c|c|}
\hline Species & Geography $^{\mathrm{a}}$ \\
\hline H. borneensis Taylor & IwP \\
\hline H. cylindracea Decaisne & IwP \\
\hline H. favulosa Howe & wA \\
\hline H. incrassata (Ellis) Lamouroux & wA-IwP \\
\hline H. macroloba Decaisne & $\mathrm{IwP}$ \\
\hline H. monile (Ellis \& Solander) Lamouroux & wA-IwP? \\
\hline H. simulans Howe & wA-IwP? \\
\hline H. stuposa Taylor & IwP, \\
\hline H. melanesica Valet & $\mathrm{IwP}$ \\
\hline H. fragilis Taylor & IwP \\
\hline H. micronesica Yamada & IwP \\
\hline H. cryptica Colinvaux \& Graham & wA \\
\hline H. cuneata Hering & $\mathrm{I}^{\mathrm{b}}$ \\
\hline H. discoidea Decaisne & A-IP \\
\hline H. gigas Taylor & IwP \\
\hline H. lacunalis Taylor & IwP \\
\hline H. macrophysa Askenasy & IwP \\
\hline H. magnidisca Noble & IwP \\
\hline H. scabra Howe & wA \\
\hline H. taenicola Taylor & IwP \\
\hline H. tuna (Ellis \& Solander) Lamouroux & M-wA-IwP \\
\hline H. xishaensis Dong \& Tseng & IwP? \\
\hline H. hummii Ballantine & wA \\
\hline H. bikinensis Taylor & IwP \\
\hline H. gracilis Harvey ex J. Agardh & wA-IwP \\
\hline H. lacrimosa Howe & wA \\
\hline H. copiosa Goreau \& Graham ${ }^{\mathrm{c}}$ & wA-IwP \\
\hline H. distorta (Yamada) Colinvaux & $\mathrm{IwP}$ \\
\hline H. goreauii Taylor & wA \\
\hline H. minima (Taylor) Colinvaux & $\mathrm{IwP}$ \\
\hline H. opuntia (L.) Lamouroux & wA-IwP \\
\hline H. renschii Hauck & IwP \\
\hline H. velasquezii Taylor & IwP \\
\hline
\end{tabular}

References for species are in Hillis-Colinvaux (1980). Halimeda hummii Ballantine (1982), H. magnidisca Noble (1986), and H. xishaensis Dong and Tseng (1980) have since been added. Taxa in boldface are included in this study.

${ }^{\mathrm{a}} \mathrm{A}=$ Atlantic, $\mathrm{I}=$ Indian Ocean, $\mathrm{P}=$ Pacific Ocean, $\mathrm{M}=$ Mediterranean Sea, w = only western, "?" = distribution not known.

${ }^{\mathrm{b}}$ Species is reported only from subtropical regions.

${ }^{\mathrm{c}} \mathrm{H}$. hederacea Colinvaux has been merged into $H$. copiosa by Colinvaux (1969).

genus. The extensive phylogeny is used to examine the evolution of phenotypic and life-history traits. We also evaluate how biogeography (Avise, 2000; Veron, 1995) and reef ecology (Wanntorp et al., 1990) affected evolution and how all the information corresponds with evidence from the fossil record.

\section{Materials and methods}

Taxa used in this study are listed in Table 2. Freshly collected thalli were immersed in $95 \% \mathrm{v} / \mathrm{v}$ ethanol and kept refrigerated in the dark until used for anatomical examination and DNA extraction. All identifications of Halimeda were based on Ballantine (1982), Noble (1986), and re-descriptions of earlier described taxa in 
Table 2

Specimens used in analyses and their collection site. Halimeda specimens are listed in the same order as they appear in Fig. 1

\begin{tabular}{|c|c|c|c|c|c|c|}
\hline Taxon & Voucher & Region & Geographical location & Latitude & Longitude & GenBank \\
\hline H. incrassata & $99-087$ & BAH & Lee Stocking I. & $23^{\circ} 45^{\prime} \mathrm{N}$ & $76^{\circ} 05^{\prime} \mathrm{W}$ & AF407233 \\
\hline H. simulans & 97-089 & CAR & I. Escudo de Veraguas, Panama & $9^{\circ} 06^{\prime} \mathrm{N}$ & $81^{\circ} 30^{\prime} \mathrm{W}$ & AF407235 \\
\hline H. monile & $98-034$ & CAR & Puerto Morelos, Mexico & $21^{\circ} 30^{\prime} \mathrm{N}$ & $86^{\circ} 30^{\prime} \mathrm{W}$ & AF407234 \\
\hline H. cylindracea & $99-150$ & WP & New Caledonia & $23^{\circ} 00^{\prime} \mathrm{S}$ & $167^{\circ} 00^{\prime} \mathrm{E}$ & AF407236 \\
\hline H. melanesica* & L.0238145 & WP & Taka Garlarang Atoll, Indonesia & $6^{\circ} 28^{\prime} \mathrm{S}$ & $121^{\circ} 18^{\prime} \mathrm{E}$ & AF407237 \\
\hline H. stuposa & L. 0238148 & $\mathrm{CP}$ & Naen Island, Rongelap Atoll & $12^{\circ} 00^{\prime} \mathrm{N}$ & $167^{\circ} 00^{\prime} \mathrm{E}$ & AF407238 \\
\hline H. borneensis & $99-127$ & $\mathrm{n}-\mathrm{IO}$ & Zanzibar & $6^{\circ} 00^{\prime} \mathrm{S}$ & $39^{\circ} 30^{\prime} \mathrm{E}$ & AF407239 \\
\hline H. macroloba & $99-129$ & $\mathrm{n}-\mathrm{IO}$ & Zanzibar & $6^{\circ} 00^{\prime} \mathrm{S}$ & $39^{\circ} 30^{\prime} \mathrm{E}$ & AF407240 \\
\hline H. incrassata & $99-073$ & PHI & Lapu Lapu, Mactan I., Cebu & $10^{\circ} 10^{\prime} \mathrm{N}$ & $124^{\circ} \mathrm{E}$ & AF407241 \\
\hline H. incrassata & $99-001$ & $\mathrm{CP}$ & Tahiti & $17^{\circ} 30^{\prime} \mathrm{S}$ & $150^{\circ} 45^{\prime} \mathrm{W}$ & AF407242 \\
\hline H. micronesica* & $99-050$ & GBR & Townsville & $19^{\circ} \mathrm{S}$ & $147^{\circ} \mathrm{E}$ & AF407243 \\
\hline H. cryptica & $97-482$ & CAR & Discovery Bay, Jamaica & $18^{\circ} 40^{\prime} \mathrm{N}$ & $77^{\circ} 20^{\prime} \mathrm{W}$ & AF407244 \\
\hline H. fragilis & $99-092$ & Guam & Bile Bay, & $13^{\circ} 30^{\prime} \mathrm{N}$ & $144^{\circ} 45^{\prime} \mathrm{E}$ & AF407245 \\
\hline H. tuna & $98-038$ & CAR & Puerto Morelos, Mexico & $21^{\circ} 30^{\prime} \mathrm{N}$ & $86^{\circ} 30^{\prime} \mathrm{W}$ & AF407248 \\
\hline H. tuna & $99-043$ & MED & Ischia I. Italy & $40^{\circ} 45^{\prime} \mathrm{N}$ & $13^{\circ} 55^{\prime} \mathrm{E}$ & AF407250 \\
\hline H. discoidea & $97-547$ & CAN & Gran Canaria & $28^{\circ} 00^{\prime} \mathrm{N}$ & $15^{\circ} 30^{\prime} \mathrm{W}$ & AF407249 \\
\hline H. hummii* & $99-052$ & CAR & STRI Sta., San Blas, Panama & $9^{\circ} 32^{\prime} \mathrm{N}$ & $78^{\circ} 57^{\prime} \mathrm{W}$ & AF407247 \\
\hline H. lacunalis & $99-095$ & Guam & Bile Bay, & $13^{\circ} 30^{\prime} \mathrm{N}$ & $144^{\circ} 45^{\prime} \mathrm{E}$ & AF407246 \\
\hline H. macrophysa & $98-125$ & GBR & Lizard Island & $14^{\circ} 15^{\prime} \mathrm{S}$ & $145^{\circ} 27^{\prime} \mathrm{E}$ & AF407251 \\
\hline H. gigas & $99-102$ & Guam & Cocos I., & $13^{\circ} 30^{\prime} \mathrm{N}$ & $144^{\circ} 45^{\prime} \mathrm{E}$ & AF407252 \\
\hline H. magnidisca & $99-027$ & SOC & Bidolih, Nogid, S-coast & $12^{\circ} 20^{\prime} \mathrm{N}$ & $53^{\circ} 00^{\prime} \mathrm{E}$ & AF407253 \\
\hline H. discoidea & $99-032$ & SOC & Bindar di-Sab, Rhiy di-Isfir, NW-coast & $12^{\circ} 30^{\prime} \mathrm{N}$ & $53^{\circ} 30^{\prime} \mathrm{E}$ & AF407254 \\
\hline H. taenicola & 99-004 & $\mathrm{CP}$ & Tahiti & $17^{\circ} 30^{\prime} \mathrm{S}$ & $150^{\circ} 45^{\prime} \mathrm{W}$ & AF407255 \\
\hline H. cuneata & $98-201$ & s-IO & Scottburgh, South Africa & $30^{\circ} 17^{\prime} \mathrm{S}$ & $30^{\circ} 47^{\prime} \mathrm{E}$ & AF407256 \\
\hline H. gracilis & HEC-11839 & IO & Beruwala, Sri Lanka & $6^{\circ} 30^{\prime} \mathrm{N}$ & $79^{\circ} 57^{\prime} \mathrm{E}$ & AF407257 \\
\hline H. lacrimosa* & 95-BA-010 & BAH & Lee Stocking I. & $23^{\circ} 45^{\prime} \mathrm{N}$ & $76^{\circ} 05^{\prime} \mathrm{W}$ & AF407258 \\
\hline H. gracilis & $99-109$ & CAR & Galeta, Panama & $9^{\circ} 24^{\prime} \mathrm{N}$ & $79^{\circ} 52^{\prime} \mathrm{W}$ & AF407259 \\
\hline H. goreauii $^{*}$ & $97-082$ & CAR & Cayo Zapatilla, Panama & $9^{\circ} 14^{\prime} \mathrm{N}$ & $82^{\circ} 00^{\prime} \mathrm{W}$ & AF407260 \\
\hline H. copiosa* & $97-080$ & CAR & Cayo Zapatilla, Panama & $9^{\circ} 14^{\prime} \mathrm{N}$ & $82^{\circ} 00^{\prime} \mathrm{W}$ & AF407261 \\
\hline H. renschii ${ }^{*}$ & $99-114$ & PNG & S-W of Wongat I., Madang & $5^{\circ} 00^{\prime} \mathrm{S}$ & $146^{\circ} 00^{\prime} \mathrm{E}$ & AF407262 \\
\hline H. minima & $99-026$ & SOC & Bidolih, Nogid, S-coast, & $12^{\circ} 20^{\prime} \mathrm{N}$ & $53^{\circ} 00^{\prime} \mathrm{E}$ & AF407263 \\
\hline H. minima & $99-025$ & SOC & $2 \mathrm{~km} \mathrm{~N}$. of Rhiy di-Quatanhin, SW-tip & $12^{\circ} 30^{\prime} \mathrm{N}$ & $53^{\circ} 30^{\prime} \mathrm{E}$ & AF407264 \\
\hline H. minima & 99-098 & Guam & Apra Harbor, & $13^{\circ} 30^{\prime} \mathrm{N}$ & $144^{\circ} 45^{\prime} \mathrm{E}$ & AF407265 \\
\hline H. opuntia & $98-088$ & CAR & I. Colon, Panama & $9^{\circ} 20^{\prime} \mathrm{N}$ & $82^{\circ} 14^{\prime} \mathrm{W}$ & AF407266 \\
\hline H. opuntia & $99-044$ & GBR & Townsville, GBR, Australia & $19^{\circ} \mathrm{S}$ & $147^{\circ} \mathrm{E}$ & AF407267 \\
\hline H. distorta & $98-121$ & GBR & Lizard Island & $14.20^{\circ} \mathrm{S}$ & $145^{\circ} 27^{\prime} \mathrm{E}$ & AF407268 \\
\hline H. hederacea & $99-045$ & GBR & Townsville, GBR, Australia & $19^{\circ} \mathrm{S}$ & $147^{\circ} \mathrm{E}$ & AF407269 \\
\hline U. flabellum & $98-196$ & CAR & Portobelo, Panama & $9^{\circ} 28^{\prime} \mathrm{N}$ & $79^{\circ} 00^{\prime} \mathrm{W}$ & AF407270 \\
\hline P. capitatus & $98-181$ & CAR & STRI Sta., San Blas, Panama & $9^{\circ} 32^{\prime} \mathrm{N}$ & $78^{\circ} 57^{\prime} \mathrm{W}$ & AF407271 \\
\hline
\end{tabular}

BAH, Bahamas; CAR, Caribbean; CAN, Canary Islands; MED, Mediterranean Sea; PHI, Philippines; SOC, Socotra Indian Ocean; IO, Indian Ocean; WP, western Pacific; CP, central Pacific; GBR, Great Barrier Reef; s, southern, and n, northern.

ITS2 could not be amplified of specimens marked "*".

Hillis-Colinvaux (1980) and were verified in case of ambiguity using original references listed in the latter. The 37 specimens of Halimeda (Table 2) used in this study were attributable to 28 of 33 currently recognized species. Outgroup species were identified using Taylor (1960) and Littler and Littler (1990). Phenotypic characters and their states were collected from specimens also included in the molecular study to permit direct comparison and avoid bias due to phenotypic differences between type specimens and ones included in this study.

DNA was extracted and purified as described in Kooistra (2002). The target region of our molecular study comprised ca. $1250 \mathrm{bp}$ of the small subunit (SSU) nrDNA, an insert therein, and the internal transcribed spacers (ITS-1, ITS-2), and 5.8S rDNA. Although we omitted the first ca. $500 \mathrm{bp}$ of the SSU, the most variable
SSU region (V4, Neefs et al., 1991) was included. Double-stranded PCR amplification and sequencing were performed as in Kooistra et al. (1999) with primers listed in Table 3. Forward and reverse sequences were compared and merged using SeqEd 1.0.3 (Applied Biosystems). Since we failed to amplify the target sequence region in one piece, we generated partial sequences overlapping in variable regions to verify common source. Base composition and length were determined with PAUP* version 4.0.b8 (Swofford, 2001).

Initially, we sequenced the ITS region of several specimens for each taxonomically recognized species in Halimeda. However, since the present study focuses on interspecific relations, we included more than one representative per species only if we encountered distinct intraspecific ITS groups or phenotypic differences. If the 
Table 3

Oligonucleotide primers used for amplification and sequencing

\begin{tabular}{|c|c|c|c|c|c|}
\hline Code & $\mathrm{F} / \mathrm{R}$ & & Location at & Use & Source \\
\hline TW3* & $\mathrm{F}$ & 5'-GCAAGTCTGGTGCCAGCATCT-3' & TW3 & $\mathrm{A}, \mathrm{S}$ & This study \\
\hline TW5* & $\mathrm{F}$ & 5'-AACTTGAAGGAATTGACGGAAG-3' & TW5 & $\mathrm{A}, \mathrm{S}$ & This study \\
\hline TW6* & $\mathrm{R}$ & 5'-GCATCACAGATCTGTTATTGCCTC-3' & TW6 & $\mathrm{A}, \mathrm{S}$ & This study \\
\hline TW7* & $\mathrm{F}$ & 5'-GAGGCAATAACAGATCTGTGATGC-3' & TW7 & $\mathrm{S}$ & This study \\
\hline H1R & $\mathrm{R}$ & 5'-TCTACGTGCGAAGGTTCAGAG-3' & $3^{\prime}$ end of $18 \mathrm{~S}$ rDNA & $\mathrm{A}, \mathrm{S}$ & This study \\
\hline $\mathrm{H} 1 \mathrm{~F}$ & $\mathrm{~F}$ & 5'-CTCTGAACCTTCGCACGTAGA-3' & $3^{\prime}$ end of $18 \mathrm{~S}$ rDNA & $\mathrm{A}, \mathrm{S}$ & This study \\
\hline ITS2* & $\mathrm{R}$ & 5'-GCTACGTCCTTCATCGACGC-3' & ITS2 & $\mathrm{A}, \mathrm{S}$ & This study \\
\hline ITS3* & $\mathrm{F}$ & 5'-GCGTCGATGAAGGACGTAGC-3' & ITS3 & $\mathrm{S}$ & This study \\
\hline ITS4 $^{\mathrm{a}}$ & $\mathrm{R}$ & 5'-TCCTCCGCTTATTGATATGC-3' & ITS4 & $\mathrm{A}, \mathrm{S}$ & White et al. (1990) \\
\hline WKR & $\mathrm{R}$ & 5'-TTTCCTCGCCGACGACATCGC-3' & $5^{\prime}$ end of $28 \mathrm{~S}$ rDNA & $\mathrm{A}, \mathrm{S}$ & This study \\
\hline
\end{tabular}

$\mathrm{A}=$ used in amplification, $\mathrm{S}=$ used for sequencing. Primers marked with a "** are modified after White et al. (1990).

${ }^{a}$ We used this primer but a perfectly fitting one reads TCCTCCGCTTAATGATATGC.

same species was collected from disjunct oceans, we included the complete sequence of at least one specimen from each region irrespective of genetic patterns.

Udotea flabellum (Ellis and Solander) Howe and Penicillus capitatus Lamarck were used as outgroup taxa. Several combinations of potential outgroups belonging to these genera, Chlorodesmis Harvey and Bailey and Flabellia Nizzamuddin were tested but all these taxa invariably formed a reciprocal outgroup clade and did not alter intrageneric topology of Halimeda. Therefore, we included only two outgroup taxa to minimize analysis time.

Merged sequences initially were aligned visually using Se-Al v1.d1 (Rambaut, 1995). Secondary structure models generated with RNAdraw (Matzura and Wennborg, 1996) allowed adjustment of the alignment in variable regions. Delineation of subunit and spacer regions was according to Hershkovitz and Lewis (1996). Matrices of pair-wise Kimura 2-parameter distances were calculated (PAUP*) for each sequence region separately and then normalized by dividing obtained values by their corresponding entries in the matrix of ITS-2 distances. Normalized distances were averaged for each region to obtain its rate relative to that of ITS-2.

Phylogenetic signal among parsimony-informative sites was assessed by comparing the measure of skewedness ( $g_{1}$-value; PAUP*) with empirical threshold values in Hillis and Huelsenbeck (1992). We used Modeltest 3.0 (Posada and Crandall, 1998) to select the best-fitting base substitution model for the sequence regions as a whole. Estimated parameters from the selected model were then imported into maximum likelihood (ML) analysis in PAUP* using the heuristic search option. Maximum parsimony (MP) phylogenies were inferred using the heuristic search procedure with the tree bisection/reconnection (TBR) swapping algorithm and the Goloboff fit criterion, $(K=2$; Goloboff, 1993) option in PAUP*. Bootstrap values (1000 replicates) for clades were obtained using MP since this procedure resulted in two equally MP trees that were nearly identical to the obtained ML tree. Bootstrapping using ML would take too long. Ambiguities were treated as such in all analyses; gaps were treated as missing data in pair-wise comparisons. We applied the partitionhomogeneity test option in PAUP* to detect possible contradictory phylogenetic histories of different sequence regions. Alternative tree topologies were evaluated using the Kishino-Hasegawa test option in PAUP*. Numbers of extra base changes needed for alternative tree topologies as well as most parsimonious explanations of phenotypic character state changes over the obtained molecular tree were evaluated using MacClade (Maddison and Maddison, 1997).

\section{Results}

\subsection{Morphological analyses}

A few specimens showed phenotypic deviations from the type specimens or their descriptions. Minute pores connected nodal siphons in the specimen of Halimeda melanesica used for DNA comparison as well as in the type. Lower thallus parts of our specimens of Halimeda hummii, including the ones for DNA analysis resembled the habit of the type but upper segments were up to $4 \mathrm{~mm}$ broad and $3.5 \mathrm{~mm}$ high and possessed an uncorticated band in the distal perimeter. Other, more minor deviations from type material were observed but these were not in the focus of this paper and will be treated elsewhere.

\subsection{Sequence analyses}

Table 4 provides data on length and $\mathrm{GC} \%$ of sequenced regions. All in- and outgroup specimens shared a ca. 100-bp insert in the SSU at an identical position, with similar secondary structure and high GC\%. The ITS regions were very short, yet $3^{\prime}$ - and $5^{\prime}$-ends of their secondary structures folded as in Venkateswarlu and 
Table 4

Sequence statistics

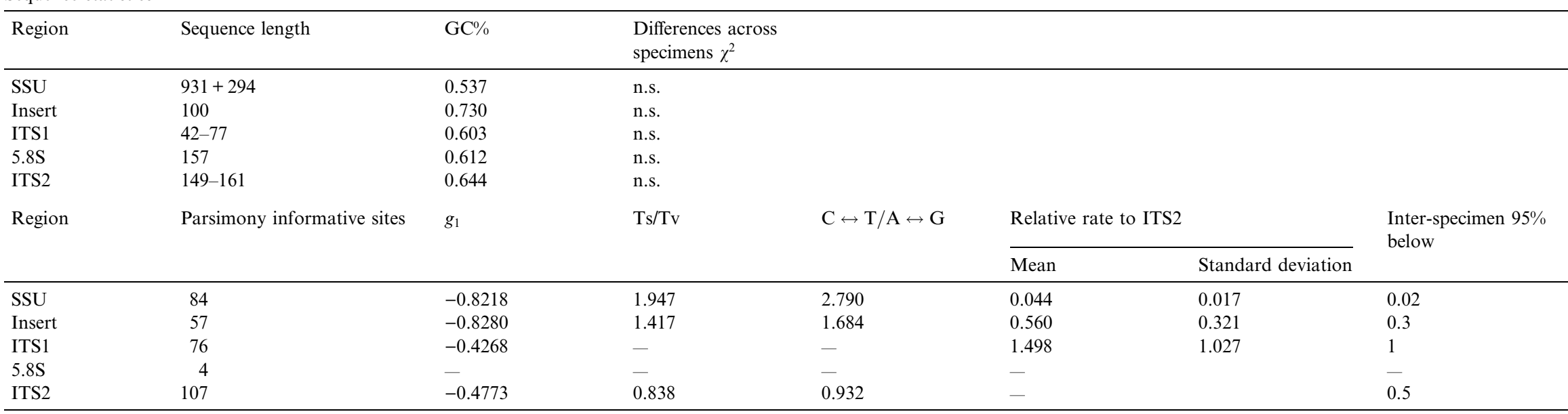

Observed across-sample GC\% differences are tested against average expectation using $\chi^{2}$ statistics. Parsimony informative sites refer to the alignment. The $g_{1}$-value is calculated using the random trees-option in PAUP*. Transition-transversion rations are calculated in MacClade with the tree in Fig. 1 as matrix. Calculations of pair-wise distances for each sequence region use the same relative substitution rates and parameters describing among site-rate variation as estimated for the whole data set by Modeltest 3.0. Obtained distance matrices are normalized against the one for ITS2. Mean and standard deviation of relative rates of a sequence region are based on all entries in the obtained normalized distance matrix. Sequences of samples indicated with a "*” in Table 2 are excluded from these comparisons since their ITS2 is unavailable. 
Nazar (1991). Although ITS-1 internal structure varied among groups of specimens, ITS-2 structure showed a basal and three peripheral stems around a central loop and at similar position in all specimens (structures not shown). Compensatory base changes supported common stems in all regions. A few ITS sequences revealed intra-individual polymorphism. Ambiguities appeared in the forward and reverse chromatograms as two bases in about equal proportions and at a similar position in different PCR products generated from the same specimen. We failed to amplify ITS-2 of specimens marked in Table 2; failure did not result from primer mismatch because other combinations among forward and reverse primers across the ITS-2 region also failed to generate PCR products whereas these primer combinations were successful with templates from other taxa.

Most positions aligned readily; a few in ITS-1 could not be aligned across all taxa and were separated into groups of similar sequences to retain inter-specific information among closely related specimens without introducing phylogenetic noise. Secondary structures assisted alignment of variable positions near the $3^{\prime}$-end of ITS-2.

Table 4 also shows results of sequence comparisons. Rate variation among regions was apparent with ITS-1 evolving fastest and SSU being slowest. Ranges of pair-wise distances across specimens and transitiontransversion ratios suggested only minimal saturation in ITS-1 and 2. Rates varied between the two types of transitions, particularly in the SSU. The GC\% varied across regions but not within regions across specimens. Despite interregional rate differences and positional rate variation within the SSU and the ITS regions, each region contained significant phylogenetic signal ( $g_{1}$-values of each region separately, see Table 4). Results of a partition-homogeneity test between SSU and the insert on the one hand and the ITS and 5.8S regions on the other showed no significant difference $(p=0.125)$, so we pooled the regions for phylogenetic analysis. Results of Modeltest also indicated data complexity; the program selected a general time-reversible base-substitution model and accounted for regional rate differences, invariable sites, and skewed base composition.

\subsection{Phylogeny}

The phylogeny in Fig. 1 resulted from ML analysis preset with values for all parameters obtained with Modeltest. Outgroup taxa were used to root the tree and then pruned away. The tree was topologically almost identical to two MP trees obtained with weighted MP (Goloboff criterion, $K=2$; trees not shown) and only one step shorter. These trees only differed from the one in Fig. 1 in that Halimeda lacunalis and Atlantic Halimeda discoidea in lineage 3 swapped position. Since MP consumed far less computational time, bootstrapping was performed only with this algorithm, though without Goloboff weighting.

The tree revealed five well-supported lineages. Mediocre bootstrap support for the clade with lineages 3,4 , and 5 was due to the unresolved position of lineages 2 and 3. Outgroup removal from the analysis did not improve this resolution. Kishino-Hasegawa test results revealed that a topology in which lineages 2 and 3 swapped positions, though costing three more steps, was not significantly worse. All other possible topologies among the lineages within 10 more steps from that of the ML tree did not pass this test (Fig. 1).

Intra-lineage relationships were not resolved satisfactorily within lineages 2 and 3 . In lineage 2, Halimeda cryptica could become sister of Halimeda fragilis and Halimeda micronesica at the expense of only one extra step, and this topology was not significantly worse (Kishino-Hasegawa test; $p=0.300$ ). Lineage 3 could also be rearranged at the expense of only one extra step to accommodate an alternative topology with $H$. hummii and $H$. lacunalis in a sister clade to the remainder of lineage 3 . This topology was also not significantly worse (Kishino-Hasegawa test; $p=0.162$ ). Distortion by other lineages or outgroups was not responsible for weak resolution of lineage 3 because MP trees inferred from sequences of each lineage separately revealed the same topologies as shown in Fig. 1 with comparable or higher bootstrap values, yet topology of lineage 3 remained inconclusive. Small alterations in the alignment of variable regions neither improved resolution nor changed topology radically.

\subsection{Phylogeny and phenotype}

In Figs. 2A-D we mapped the evolution of traits associated with nodal siphon anatomy using the tree in Fig. 1 as a guide. In Figs. 2E-H we did the same with characters of cortical anatomy, and in 2I-O we examined the evolution of traits associated with thallus shape. State changes of characters mapped in Figs. 2A, B, I, and $\mathrm{L}$ showed no homoplasy if molecular phylogenetic relationships are accepted. Those mapped in Figs. 2E, F, $\mathrm{H}, \mathrm{J}, \mathrm{K}, \mathrm{M}$, and $\mathrm{P}$ converged or reversed only once or a few times. Notably, if lineages 2 and 3 swapped positions in Fig. 1, then the characters mapped in Figs. 2E, $\mathrm{F}$, and $\mathrm{M}$ change only once in each state. However, states of characters mapped in Figs. 2C, D, G, N, and O were acquired and lost several times and were therefore not good indicators of phylogeny.

The five lineages within Halimeda are defined by morphological character states. In lineage 1, medullary siphons in the nodes between segments connect with their neighbor siphons by means of pores (Fig. 2A). Segments in middle and lower regions of the mature thallus are enlarged and they agglutinate in a fan- or squat-pillar-like structure (Fig. 2I). In lineage 2, one or 


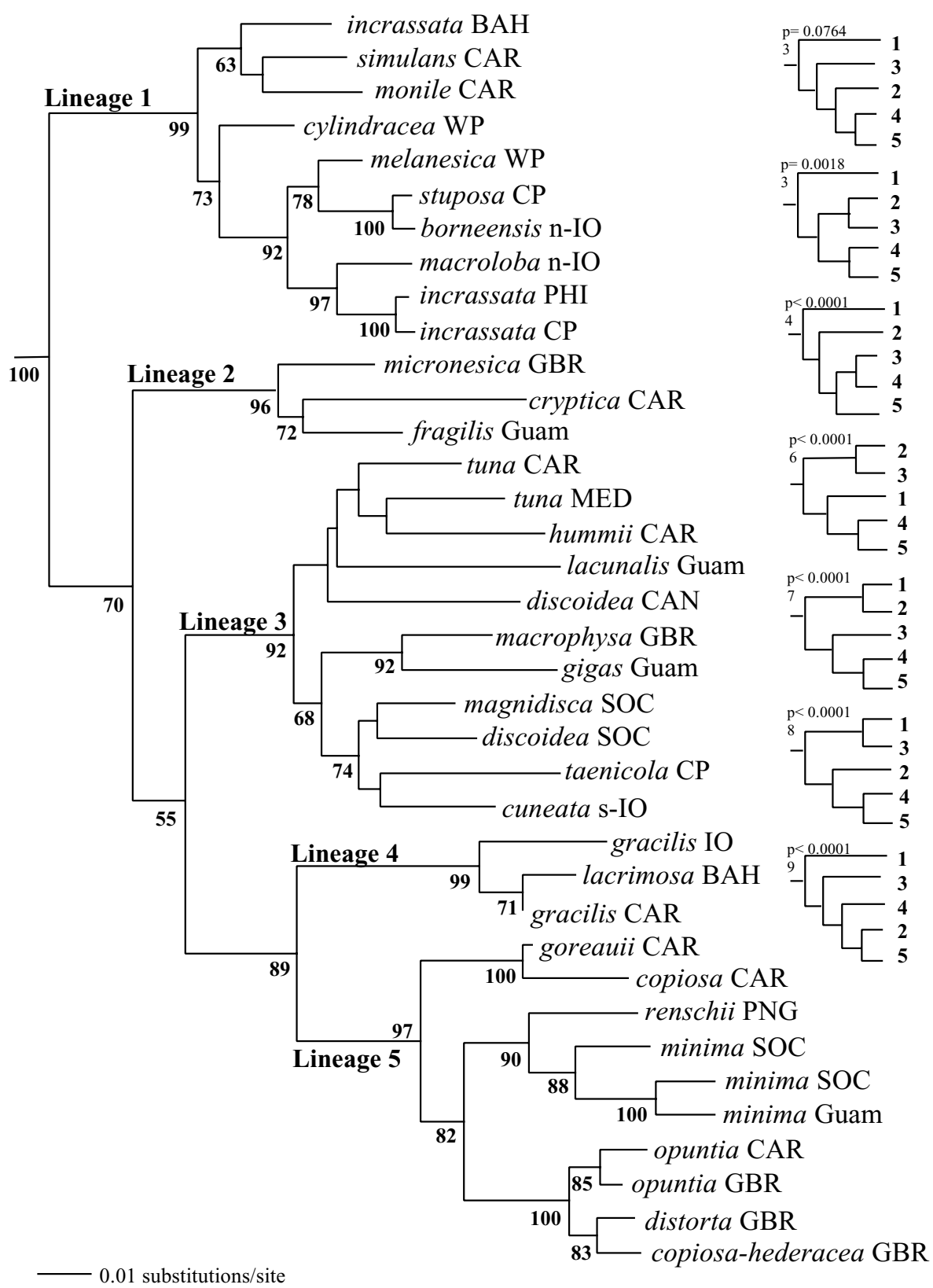

Fig. 1. Maximum likelihood phylogram inferred from partial SSU nrDNA, ITS-1, 5.8S rDNA, and ITS-2 of 37 specimens of Halimeda species and two outgroup species (see Table 2). Proportion of sites assumed to be invariable $=0.706597$; rates assumed to follow a gamma distribution with shape parameter $=0.569811$. Assumed substitution rates: $\mathrm{A} \Longleftrightarrow \mathrm{C}=1.601, \mathrm{~A} \Longleftrightarrow \mathrm{G}=1.993, \mathrm{~A} \Longleftrightarrow \mathrm{T}=1.452, \mathrm{C} \Longleftrightarrow \mathrm{G}=1.213, \mathrm{C} \Longleftrightarrow \mathrm{T}=3.486$, $\mathrm{G} \Longleftrightarrow \mathrm{T}=1.000$ (reference; input values from Modeltest). - ln likelihood $=10353.405$; Goloboff fit $=-255.009$, length $=1266$, C.I. $=0.607$, R.I. $=0.708$. Maximum parsimony bootstrap values $>50 \%$ (full heuristic search with TBR branch swapping option; 1000 replicates) are indicated in bold below internodes. Outgroup taxa were pruned from the tree. Lineages 1-5 are explained in text. All alternative topologies among the lineages within ten steps from the ML-tree are presented as cladograms. Associated Kishino-Hasegawa test results against the ML-tree and the extra number of steps needed are indicated above these cladograms.

several thickened and enlarged medullary siphons pass unfused through the nodes (Fig. 2A). In lineage 3, medullary siphons entangle below the distal perimeter of the segment (Fig. 2B) and then fuse (predominantly completely, and in pairs and threes) in a single band in the segment rim (Fig. 2L). Lineages 4 and 5 contain species that generally grow into sprawling expanses in which discrete individuals cannot be recognized without molecular tools. In lineage 4, secondary cortical utricles expand only at their apex (Fig. 2F). In lineage 5, nodal medullary siphons fuse briefly (in pairs and threes) without losing their identity (Fig. 2A). Several traits can be used to separate one set of lineages from the remainder, e.g., the branching mode of utricles in the cortex of segments. These traits are useful for identification purposes and can be gleaned from Fig. 2 . 


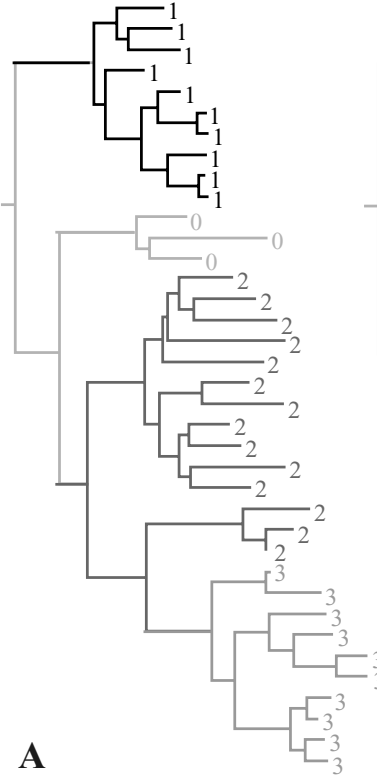

Medullary siphons at node: 0 , no fusion; 1 , fusion of all siphons through lateral pores; 2 , complete fusion of two or three siphons; 3 , brief fusion between pairs but siphons maintain identity.

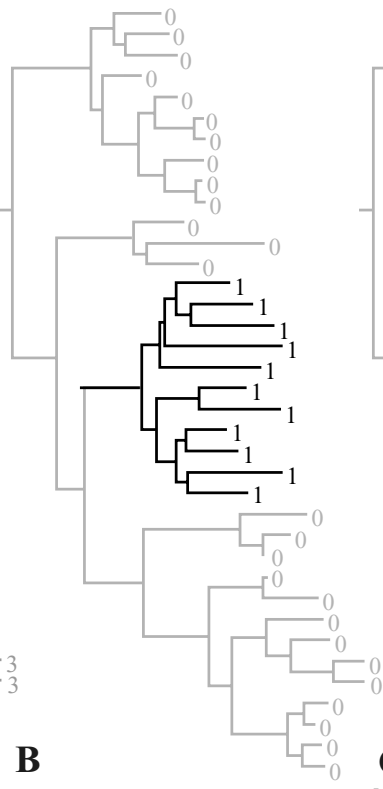

Medullary siphons below node: 1 , branch profusely and entangle; 0 , not so.

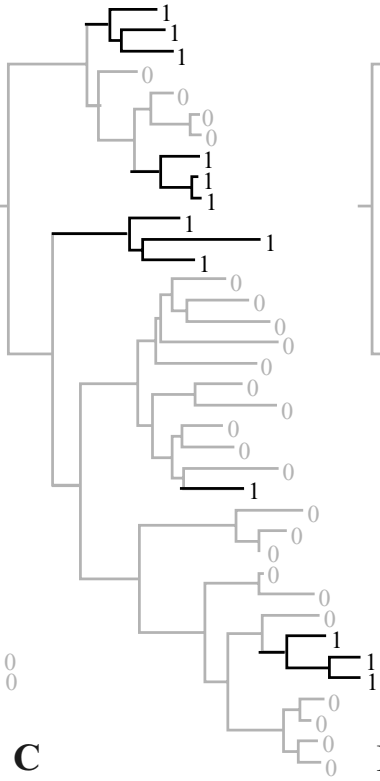

Medullary siphon walls at node:

1 , thick and pigmented; 0 , not so.

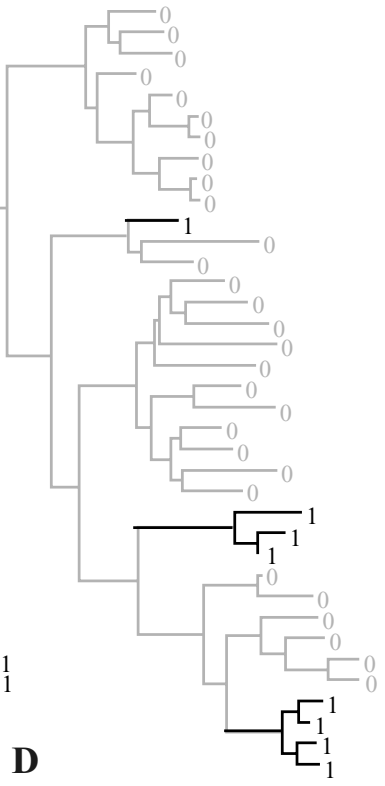

Tips of medullary siphons at uncorticated regions in upper rim of segment:

1 , can form secondary

holdfasts; 0 , not so.

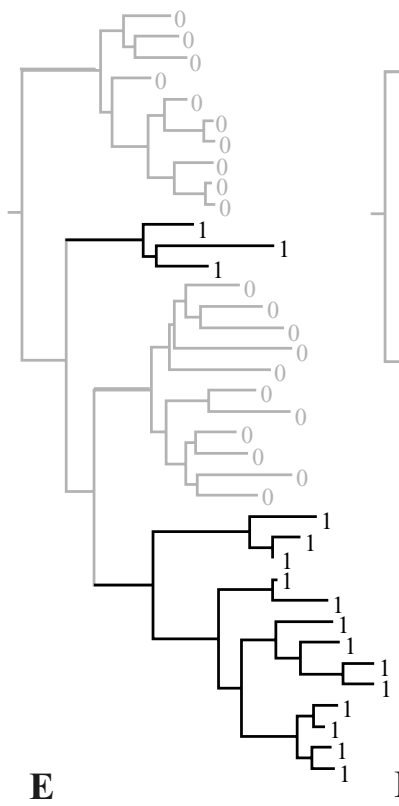

Cortical utricles directly underneath peripheral ones: 0 , constricted, branching trichotomously or chaotically; 1 , not constricted, branching dichotomously.

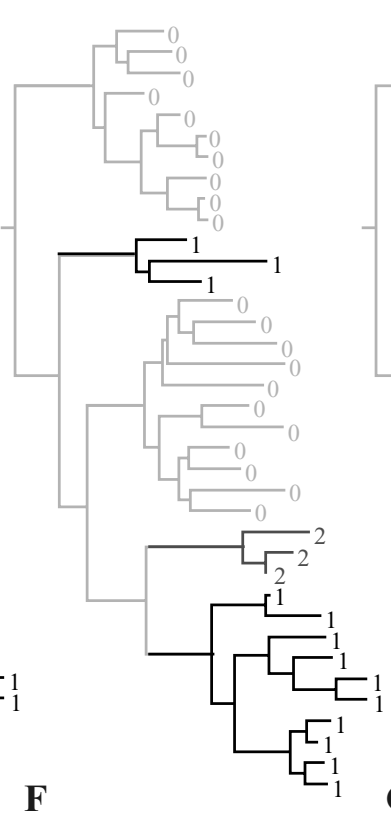

Cortical utricles directly underneath peripheral ones:

0 , swollen throughout; 1 , not swollen; 2, club-shaped.

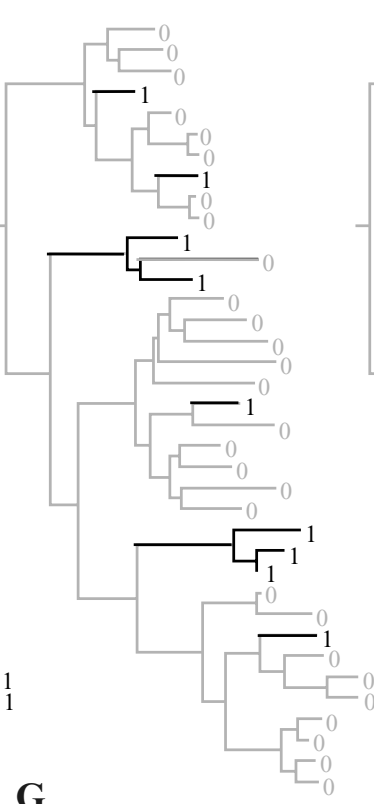

Peripheral cortical utricles:

0 , hexagonal, adhering;

1 , round, loose.

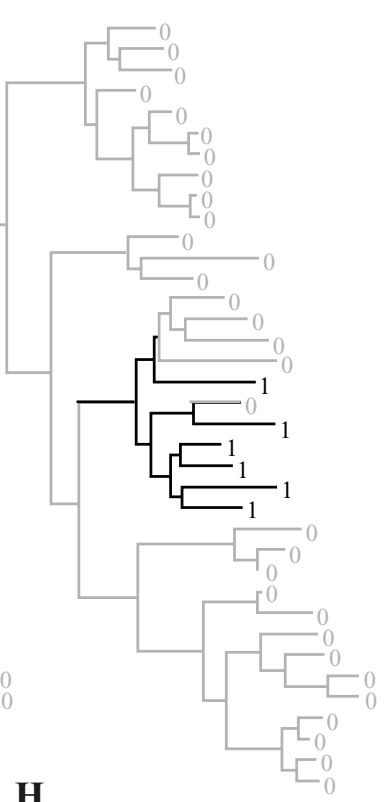

Peripheral cortical utricles:

0 , never fuse;

1 , can fuse incidentally.

Fig. 2. Phylograms as in Fig. 1 with the most parsimonious explanation of changes in a series of morphological characters mapped on the branches.

\subsection{Historical ecology}

Ecological affinity of species as obtained from personal observations, from communication with various collectors, and from literature (Ballantine, 1982; HillisColinvaux, 1980, 1986; Noble, 1986; Taylor, 1950) was mapped on the phylogenetic tree (Figs. 3A-C). The most parsimonious explanation for confinement to 


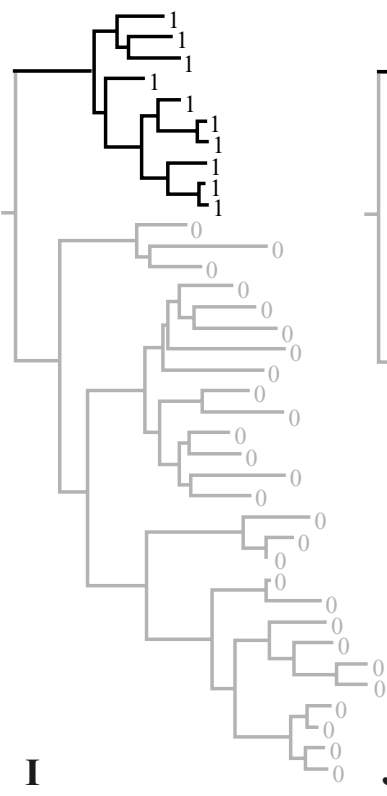

lower segments of thallus: 1 , enlarged and agglutinated with neighbor segments into fan- or squat pillar like structure; 0 , not so.

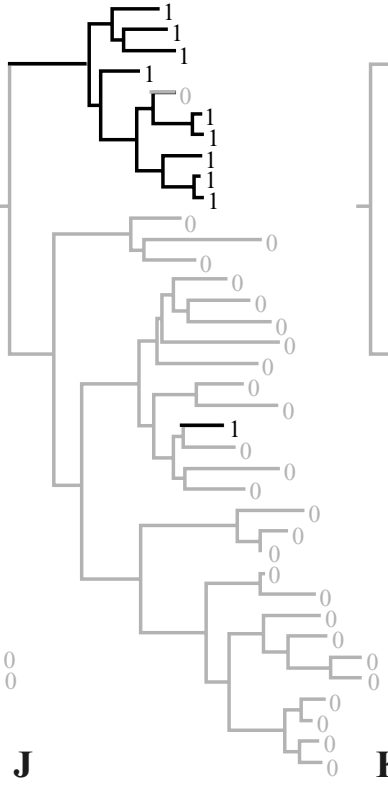

Lower segments of thallus: 1 , of equal height, heavily calcified and stipitate; 0 , of unequal height, not stipitate.

Holdfast: 0, matted, on rock;

1 , bulbous, in loose substrate.

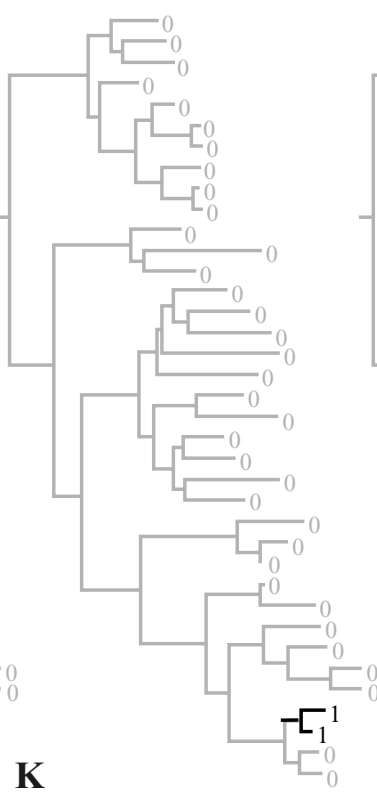

Juxtaposed segments: 0, if in different planes, then only in lowermost part of thallus; 1 , in different planes throughout.

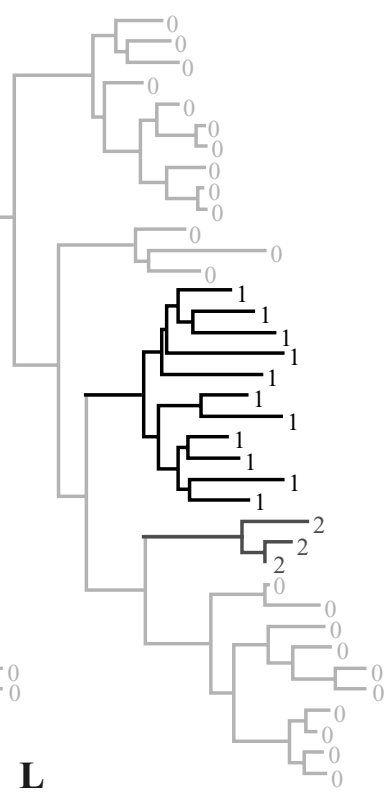

Medulla emerges in distal segment's rim in: 0 , one dominan apical and mostly 2 peripheral pits; 1 , a band; 2 , a series of pits without dominance.

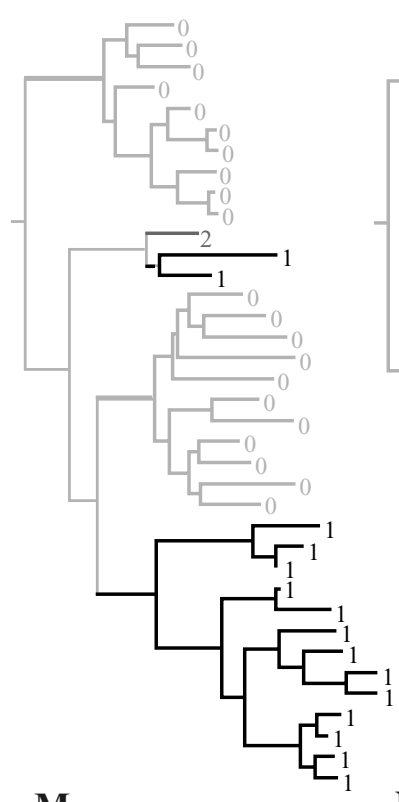

M

Basal and sub-basal segments: 0 , about equal in size and thickness to those in middle region of mature thallus; 1 , much smaller; 2 , considerably larger.

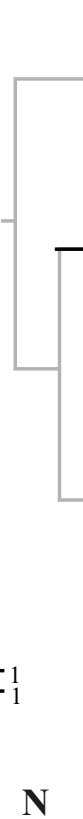

Segments in upper part of thallus: 0 , of equal size and form throughout; 1 , small, narrower than high, diminishing in size towards the end or minute

throughout; 2, large, reniform, pliable.

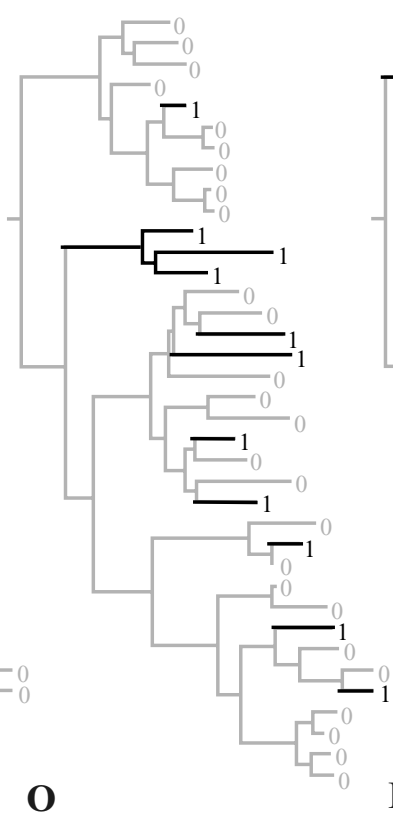

Nodal junctions of upper segments: 0, inflexible to somewhat flexible; 1 , highly flexible.

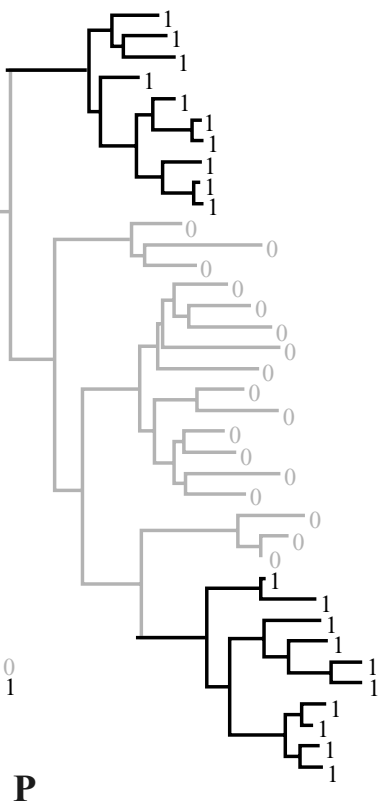

Segments: 0, not notably ribbed; 1 , ribbed or cylindrical.

Fig. 2. (continued).

unconsolidated substrata in Fig. 3A is that it appeared twice: along the basal internode of lineage 1 and independently in Halimeda magnidisca (lineage 3); it was lost secondarily in $H$. melanesica (lineage 1). Possession of a bulbous holdfast and strongly calcified stipitate lower segments (Fig. 2J) correlated perfectly with confinement 

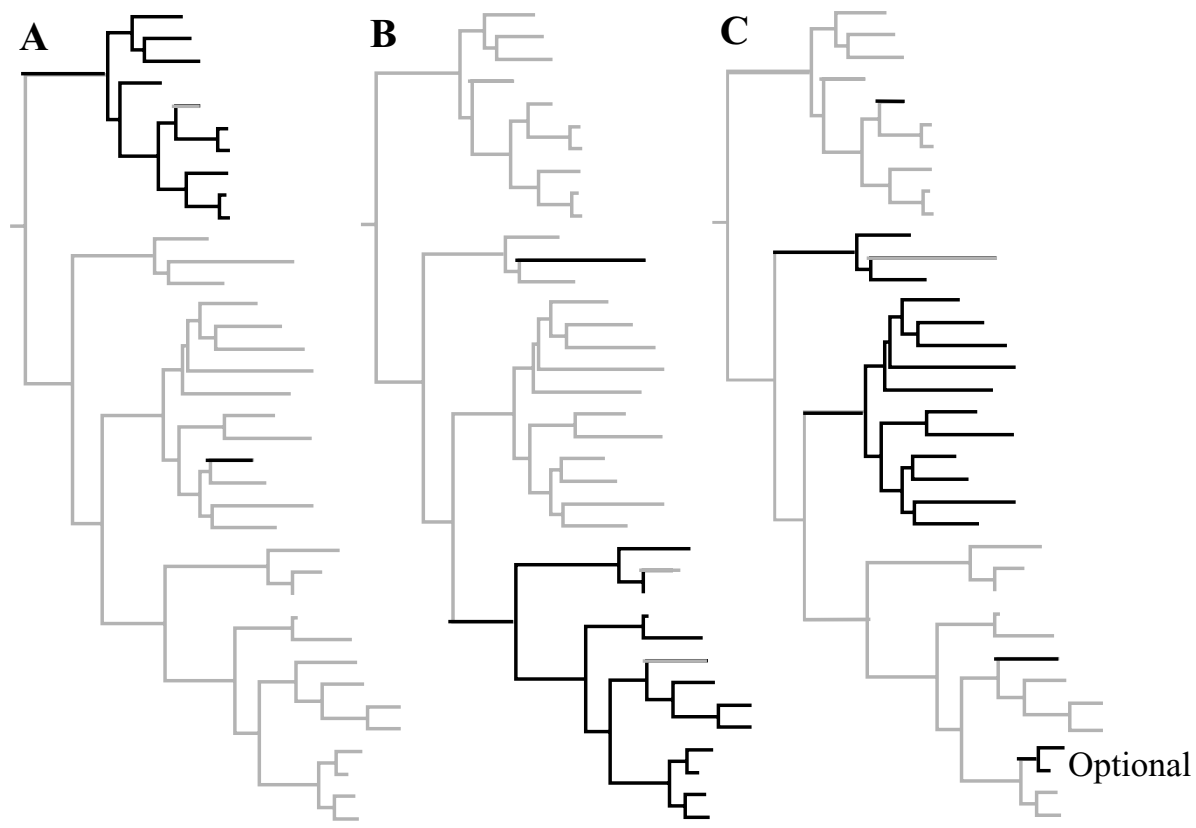

Fig. 3. Phylograms as in Fig. 1 with occurrence of the species in particular habitats marked in black and with the most parsimonious historical ecological explanations for their establishment mapped on the branches. In Fig. 3A, black indicates confinement to unconsolidated substrate and gray indicates holdfasts attaching to rock or, in some cases gravel. In Fig. 3B, black indicates occurrence in sheltered localities under high grazing pressure. In Fig. 3C, black indicates occurrence under moderate hydrodynamic energy.

to this substratum type. Agglutinated segments (Fig. 2I) also associated with sand but were encountered only in lineage 1 .

Species at sheltered and deep localities under high grazing pressure were marked in Fig. 3B. These species shared strong calcification. The feature must have appeared at least twice independently, once at the basal internode of lineages 4 and 5 and once in H. cryptica.

Thalli experiencing moderate hydrodynamic energy were marked in Fig. 3C. The most parsimonious explanation for their occurrence under such conditions revealed multiple moves into this habitat: along the basal internodes of lineages 2 and 3 and independently in H. melanesica and in Halimeda renschii. Moreover, at least two distinct phenotypes were encountered there. These phenotypes all shared flexible branches, but differed in the way flexibility was achieved. $H$. melanesica (lineage 1), $H$. micronesica and $H$. fragilis (lineage 2), $H$. hummii, H. lacunalis, Halimeda cuneata and Halimeda taenicola (lineage 3), and $H$. renschii (lineage 5) shared small, usually well-calcified segments (Fig. 2N) interspersed with flexible nodes (Fig. 2O). The nodes possessed generally thick-walled, pigmented nodal siphons (Fig. 2C) with reduced fusion patterns, or a complete lack of fusion (lineage 2). Fig. $3 \mathrm{C}$ revealed that this phenotype was acquired several times independently. The other phenotype showed large, pliable segments (Fig. 2N) with swollen utricles (Fig. 2F) and broadened nodal junctions along the uncorticated band in the segment's rim (Fig. 2L). Species deploying this phenotype were only encountered in lineage 3. Notably, it emerged only once in the alternative topology of lineage 3 as depicted in Fig. 4.

Several other species showed plastic adjustment to water motion but these had their main distribution in sheltered environments. Tall sand-growing species in lineage 1 possessed flexible branches in their upper thalli but these became stiff and more compact at shallow, wave-affected sites. Halimeda opuntia, which formed sprawls over sheltered rocks, became more compact and cushion-shaped at such shallow sites whereas thalli of Halimeda goreauii, which formed draperies at protected sites, became more fan-shaped at the exposed limits of their distribution.

\subsection{Phylogeography}

Superimposition of sample sites (Tables 1 and 2) over the molecular phylogeny revealed comparable patterns of Atlantic and Indo-Pacific groups in all lineages (Fig. 4). Lineages 1 and 4 diverged into Atlantic and IndoPacific sister clades. Although lineages 2 and 3 did not do so, the alternative topology of lineage 2 did separate perfectly, whereas that of lineage 3 separated into two sister clades separating in their turn into Atlantic and Indo-Pacific daughters. The only lineage defying strict Atlantic-Indo Pacific vicariance was lineage 5 because H. opuntia was monophyletic and encountered in both ocean systems. 


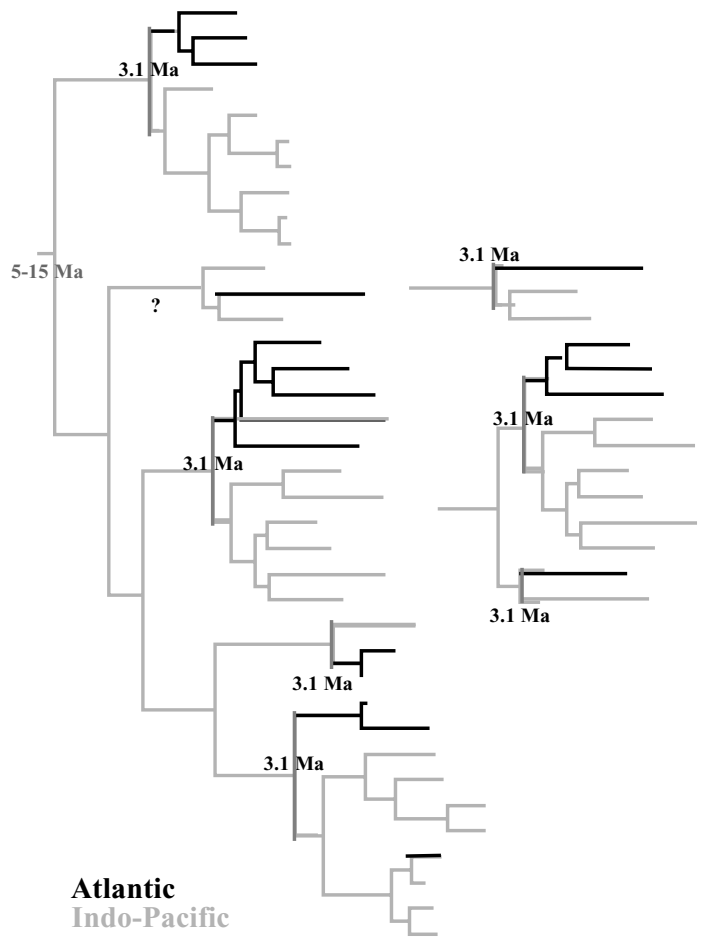

Fig. 4. Phylogram as in Fig. 1 with geographic locality replacing taxon names and with the most parsimonious phylogeographical explanation for their establishment mapped on the branches. The alternative topology of lineage 2 makes $H$. cryptica Atlantic sister to the Indo-Pacific species. The alternative for lineage 3 places $H$. hummii and $H$. lacunalis in a sister clade to the remainder of lineage 3 . The alternatives take one extra step, each.

In Fig. 1, Halimeda tuna from the Atlantic and $H$. tuna from the Mediterranean were not nearest neighbors. Yet in the alternative topology of lineage 3, they became geminates-genetically distinct but phenotypically similar nearest neighbors. All the remaining so-called pan-tropical species, Halimeda copiosa, $\mathrm{H}$. discoidea, Halimeda gracilis, and Halimeda incrassata, consisted of Indo-Pacific and Atlantic cognate pairsphenotypically similar but para- or polyphyletic entities (Fig. 4). Although monophyly for $H$. gracilis required only one extra step in the molecular tree, for H. copiosa, $H$. discoidea, and $H$. incrassata this would cost 23, 28, and 15 steps, respectively. A re-evaluation of the anatomy of $H$. discoidea revealed peripheral utricles in IndoPacific specimens attaching for up to $40 \mu \mathrm{m}$ and those of Atlantic specimens adhering only along their peripheral margin. Two look-alike pairs, the Indo-Pacific Halimeda minima and Atlantic $H$. goreauii and the Indo-Pacific Halimeda borneensis and Atlantic Halimeda simulans were not nearest neighbors either.

\section{Discussion}

The obtained molecular phylogeny serves as a blueprint for exploring phenotypic evolution, historical ecology, phylogeography, and paleontology of the extant Halimeda diversity and to reflect the phenotypic evolution of this diversity with stratophenetic evidence from the fossil record. However, before these topics can be addressed, it is necessary to discuss quality and structure of sequences and inferred phylogenies.

\subsection{Sequence comparisons and phylogenetic analyses}

Comparison of nrDNA sequences across the chlorophyll $\mathrm{a}+\mathrm{b}$ algal diversity (e.g., Hershkovitz and Lewis, 1996; Mai and Coleman, 1997; Nakayama et al., 1998) reveals how unusual these regions in fact are in Halimeda. Inclusion of SSU nrDNA sequences of Halimeda and Caulerpa in phylogenetic analyses results in trees in which these taxa appear as close sisters on an extremely long branch (Zechman et al., 1999). Elevated SSU substitution rates even affect conserved PCR primer targets since the primers used here deviate from universal ones in White et al. (1990). Nevertheless, SSU secondary structures conform to the model in Gutell (1993) indicating functionality.

The identical location of the SSU insert in all tested representatives across Halimedineae and Caulerpaceae (this study, Durand et al., 2002; Hillis et al., 1998; Kooistra, 2002; Kooistra et al., 1999) indicates its conserved existence. Its relatively slow substitution rate in comparison to the ITS regions, conserved length, similar secondary structure, and high $\mathrm{CG}^{\%} \%$ in Halimeda suggest functionality in the mature ribosome and the existence of a novel conserved region in the SSU.

The short ITS regions demonstrate how just a few positions can accomplish proper folding (Venkateswarlu and Nazar, 1991) and auto-excision. Several ITS-2 positions, believed to be constant across Chlorophyta (Coleman and Mai, 1997; Mai and Coleman, 1997) differ or are lacking in Halimeda. Conserved secondary structure and compensatory base changes among the nrDNA sequences included here indicate functionality. Short ITS sequences could result from selection against redundant DNA. Indeed, Halimeda nuclei are small (Gori, 1979; Meinesz, 1980). Moreover, thalli possess nuclei of various ploidy levels: large, polyploid nuclei remain confined to the medulla and inner cortex whereas small, diploid ones can pass through the narrowest siphons or constrictions therein (Kapraun, 1994).

The fact that both SSU and ITS sequences provide significant signals of the same phylogeny is quite peculiar because these sequences evolve at widely different tempos. In general ITS sequences become difficult to align as soon as the much slower SSU arrives within the window of phylogenetic interpretability (Bakker et al., 1994, 1995a, 1995b). In Halimeda, however, elevated rates of SSU regions in comparison to those of other green algae (Zechman et al., 1999) close in on depressed rates among ITS regions. The depression is expected 
because of a relatively high proportion of conserved functional core positions (Coleman and Mai, 1997; Hershkovitz and Lewis, 1996) in the short sequences of Halimeda (this study) in comparison to much longer ones found in other green algae (e.g., Bakker et al., 1995a,b).

Despite the differing substitution rates and modes, no discordance in phylogenetic history could be detected between the SSU and ITS regions. Therefore, we could combine the various nrDNA regions in a single phylogenetic analysis. Such is not always appropriate, e.g., when different sequence regions produce conflicting phylogenies (Durand et al., 2002). In Caulerpa racemosa, Famà et al. (2000) and Durand et al. (2002) revealed considerable intra-individual ITS sequence variation and the latter authors also showed conflict between trees inferred from the insert and ones from the ITS regions, all suggestive of hybridization events. Ribosomal RNA coding regions are particularly prone to introgression (Nichols, 2001; Riseberg and Wendel, 1993; Sang et al., 1995; Wendel et al., 1995) because of their multi-copy nature (Jorgensen and Cluster, 1988).

\subsection{Phylogeny and taxonomy}

Although the tree supports the relevance of medullary siphon patterns at nodes (Barton, 1901) for a natural taxonomy, it rejects the sectional treatment of HillisColinvaux (1980). A detailed comparison of our results with her proposed sections as well as other taxonomic details will be dealt with in another paper.

Although our specimens of $H$. melanesica and $H$. hummii deviated morphologically from their type descriptions, these deviations corroborated their phylogenetic position. For instance, the minute pores at the nodes in $H$. melanesica had not been observed as such by Valet (1966). Yet, they are a derived character state, shared with all members of lineage 1. Similarly, the uncorticated band in the segment rim of $H$. hummii is a derived character state that is shared among all members of lineage 3 . In part, such deviations may result from phenotypic plasticity. Many Halimeda species show considerable plasticity resulting from environmental variation (Gilmartin, 1960; Hillis-Colinvaux, 1980; Mariani-Colombo and Orsenigo, 1977; Stark et al., 1969). This variation readily exceeds the limits of taxonomically perceived species and some extremes may have been described as distinct species. For example, Fig. 1 suggests that Halimeda stuposa is just a compact growth form of anatomically similar $H$. borneensis. Halimeda cylindracea and Indo-Pacific $H$. incrassata also form more compact thalli in wave-affected shallows (Gilmartin, 1960; this study). Comparable environmentally induced plasticity has been observed in coral species (Veron, 1995) occurring along environmental gradients also occupied by Halimeda species.
The large number of look-alikes also poses a challenge to taxonomists. They came about through convergence or parallelism. Since these cases are closely linked to historical ecology and phylogeography, they will be discussed in association with these topics.

\subsection{Historical ecology}

The most parsimonious explanation for the distribution of species in their present habitats is that the ancestor of lineage 1 adapted to sand, that of lineages 2 and 3 occupied the moderate hydrodynamic energy habitat and that of lineages 4 and 5 adapted to sheltered and heavily grazed environments. Although lineage-defining derived and ancestral states may be old adaptations, their adaptive value cannot be evaluated here because experimental data are lacking. A comparative approach will not help because species share these traits through common descent. Secondary reduction of states associated with species that jumped away from their ancestral habitat suggests, but does not prove, that the original state had some adaptive value in the old habitat; it demonstrates only that the ancestral condition is disadvantageous in the new environment. An example may be the secondary loss of unfused nodal siphons in $H$. cryptica when its ancestor moved from wave-agitated conditions into deep water. In this species, only a single, huge medullary siphon traverses the node.

Adaptive value of traits can be ascertained if they are acquired independently in species occupying similar habitats (Schluter, 2001). Independent gains and a single loss of the sand-growing habit (Fig. 3A) in concert with gain and loss of the bulbous holdfasts and stipitate lower segments (Fig. 2J) demonstrate the adaptive value of these traits. The bulbous holdfast serves as sand anchor and strongly calcified lower segments keep the thallus up and away from the substratum. These traits are not evolutionarily constrained because they have appeared twice independently. In contrast, in lineage 1 agglutination of segments (Fig. 2I), which reinforces the middle regions of thalli, might be evolutionarily constrained because $H$. magnidisca (lineage 3 ) failed to gain this trait.

Especially in sheltered localities, grazing by large herbivores governs community structure and so defense against herbivores is critical to survival (Hay and Taylor, 1985; Hay et al., 1983, 1988, 1994; Lewis and Wainwright, 1985; Steneck, 1997). Halimeda species in such environments possess precursors of intra-siphonal toxic acids as well as enhanced calcification (Duffy and Hay, 1990; Hay, 1997; Paul, 1997; Stark et al., 1969). Consumption of this tissue would activate the acids and bring them in contact with the aragonite, a most unpleasant experience for big grazers (Duffy and Hay, 1990; Hay, 1997; Paul, 1997). Intense intersiphonal calcification and stiffening of the thallus evolved twice 
independently and disappeared at least once, showing that this character is not constrained. Its correlation with existence in sheltered, grazed habitats (Fig. 3B) indicates functionality. Heavy calcification has appeared and been lost multiple times in other Udoteaceae as well, thus further supporting lack of constraint (Kooistra, 2002).

Two Halimeda phenotypes encountered in moderate hydrodynamic energy (Fig. 3C) reduce drag effectively through increased suppleness (Collado-Vides et al., 1998; Vogel, 1996). One phenotype shows increased nodal flexibility and an increased number of nodes per given branch length (Fig. 2O). Consequently, the segments themselves remain small. This phenotype evolved at least three times independently: in $H$. melanesica (lineage 1); along the basal internode of the clade with lineages 2 and 3 (in $H$. micronesica, $H$. fragilis, $H$. hummii, $H$. lacunalis, $H$. taenicola, and $H$. cuneata); and in $H$. renschii (lineage 5). A similar phenotype is even encountered in the upper regions of erect thalli of some species in lineage 1 . Thalli deploying this general phenotype often possess thickened, pigmented nodal siphons showing reduction or lack of fusion (lineage 2). Here, independent acquisitions of similar traits in similar environments prove functionality.

The other phenotypic solution to drag deploys large, pliable segments (Fig. 2N) made possible through reduced calcification. These species share large, swollen secondary utricles leaving little space for an aragonite cast. Nodes can, but do not need to, remain flexible. Here, entangled medullary siphons below the node, fusion among nodal siphons, and broad nodal junctions probably reinforce the nodal region and permit the pliable segments to become large. This solution apparently only evolved once, namely in lineage 3 . The remaining wave-adapted species did not acquire this phenotype, possibly because they were unable to gain the complete package of states required for the deployment of this phenotype. But even if the states are in place, species are not trapped in this phenotypic solution because H. magnidisca possesses narrow, flexible nodes and the cenancestor of $H$. cuneata and $H$. taenicola obviously regained flexible nodes and small segments.

Species such as $H$. magnidisca, $H$. melanesica, $H$. cryptica, and $H$. renschii altered their phenotypes through changes among anatomical traits whilst invading new habitats. Their rapid phenotypic change contrasts with apparent phenotypic stasis in genetically distinct sister species growing in comparable environments (e.g., $H$. tuna from the Mediterranean and the Caribbean, the cryptic diversity within $H$. minima). Such examples suggest that morphological evolution in $\mathrm{Hal}$ imeda fits the model of punctuated equilibrium (Gould and Eldredge, 1977).

The lineages themselves may have originated from similar niche jumps. Modern jumps are accompanied by changes among plastic characters whereas lineage-defining states are more stable. Yet, initially the latter may just have been as plastic and changeable but during subsequent specialization the acquired functional combinations of these states may have been fine-tuned with respect to one another through natural selection, thereby reducing their ability to vary (Müller, 1989; Stearns, 1992; Van Valen, 1973).

\subsection{Phylogeography}

Near-perfect separation of all lineages into Atlantic and Indo-Pacific sister clades suggests allopatric speciation through vicariance. A series of closure events separated the pan-tropical realm of the Late Tethys Sea into the disjunct tropical regions of the modern Atlantic and Indo-Pacific: the Miocene collision of Africa and Eurasia at about 12-15 Ma B.P. (Rögl and Steininger, 1984), the Pliocene emergence of the Isthmus of Panama at 3.1 Ma B.P. (Coates and Oblando, 1996) and the intensification of the Benguela cool upwelling along South-western Africa in the Late Pliocene at around 2 Ma B.P. (Shannon, 1985). Following the closure of the Panamanian Isthmus, changing current patterns minimized the strictly tropical realm along the eastern Pacific coastline (Weaver, 1990), thus explaining the present scarcity of Halimeda species on these shores; only Pacific $H$. discoidea is known from this region.

Knowledge of dispersal capacity and distribution patterns of extant and fossil Halimeda species is pivotal to identifying the event causing the split between Halimeda representatives in the Atlantic and the IndoPacific. Widespread occurrence of extant species, even on remote archipelagos (e.g., Drew, 1995; Hillis-Colinvaux, 1980, 1988; Taylor, 1950; Tsuda and Kamura, 1991; Tsuda and Wray, 1977) and pan-tropical patterns of fossil ones prior to the vicariant events (Elliott, 1981; Flügel, 1988) suggest long-distance dispersal. Such dispersal in marine organisms is considered to be a function of larval endurance in the plankton, active migrating or drifting capability, (ir)-regularity of ocean current patterns, seawater temperature tolerance limits, and habitat availability (seaweeds: Prud'homme van Reine and Van den Hoek, 1988, 1990; Van den Hoek, 1987, corals: Veron, 1995, fish: Bowen et al., 2001; Colborn et al., 2001; Muss et al., 2001, and sea urchins: Lessios et al., 1999, 2001). Although calcified thalli of Halimeda are unlikely drifters, uncalcified juvenile stages, which grow slowly for extended periods (Meinesz, 1980), could hitchhike across the ocean on drift material (Woelkerling, 1975). Indeed, trans-oceanic distances seem no barrier to dispersal because $H$. discoidea isolates from the western and eastern Atlantic showed identical SSU signatures and relationships of those from across the Pacific Ocean did not reveal any pattern (Kooistra et al., 1999; in preparation). 
If trans-oceanic dispersal occurs at present, it likely happened in the past and only the rise of the Panamanian Isthmus and the establishment of cool upwelling along south-western Africa could have barred pantropical dispersal. In that case, principal dichotomies of lineages can be dated tentatively. Although each lineage may have contained several pan-tropical species during the time of the vicariance, a single survivor in both ocean systems would give rise to a pattern apparent in lineages 1,4 , and 5 . Two such survivors in both systems would explain the alternative topology of lineage 3 (Fig. 4) whereas one survivor in the Indo-Pacific and one in both oceans explain the pattern in lineage 3 . A problem associated with dating is that principal dichotomies can have predated the vicariant events if the progeny of one species ultimately survived in the Atlantic and that of the other only in the Indo-Pacific. Nevertheless such a dichotomy cannot have predated the events by many millions of years because very early divergence would generate a jumbled distribution of Indo-Pacific and Atlantic species over species-rich lineages. The relative distances between basal dichotomies within the speciesrich lineages (vicariant event at ca. 2-3.1 Ma B.P.) and their end nodes (right now) and the root of the tree and the end nodes suggest an age of the cenancestor of the extant diversity anywhere between 7 and $15 \mathrm{Ma}$ B.P.; i.e., the Mid- to Late-Miocene.

Establishment of H. tuna (Fig. 4) in the Mediterranean Sea must postdate the termination of the Messinian salinity crisis at ca. 5 Ma B.P. (Butler et al., 1999; Riding et al., 1998) when the basin finally reopened to the Atlantic Ocean. The species is not a recent immigrant from the Red Sea because apart from being closely related to western Atlantic species, it was described from the Mediterranean before the opening of the Suez Canal (Imperato, 1599 in Hillis-Colinvaux, 1980). Although immigration could have occurred anytime between the Pliocene and 1599, the range adds a time-constraint on a node in the phylogeny independent of the rise of the Isthmus of Panama.

Inter-oceanic dispersal seems to be uncommon in Halimeda since only $H$. opuntia managed to jump from the Indo-Pacific into the Atlantic. This event might be recent and might even have occurred between the onset of inter-oceanic shipping and the species' first record in the Caribbean. The recent fossil record may uncover the time of its arrival. Its extremely broad plasticity range and dominance in many reef habitats all over the Caribbean (see illustrations of $H$. opuntia $f$. tri$l o b a=$ shaded form of $H$. opuntia in Littler and Littler (2000, p. 406)) suggest invasiveness comparable to that of some Caulerpa species (Famà et al., 2000; Jousson et al., 1998). The Indo-Pacific representatives share the habitat with several other Halimeda species (H. distorta, $H$. hederacea, $H$. micronesica, $H$. minima) and do not cover reefs to the same extent as their Caribbean rela- tives. Only a few other seaweed phylogeographic studies have elucidated dispersal directionality (Bakker et al., 1995b; Peters et al., 1997; Van Oppen et al., 1995).

\subsection{Convergence}

Thallus shape of niche-jumping species such as $H$. melanesica, $H$. cryptica, $H$. magnidisca, and $H$. renschii converged on that of Halimeda species already present in their newly invaded environments. Yet, lineage-defining states still betray the origin of these "jumpers". These states may even be disadvantageous in the new environment; e.g., $H$. renschii failed to enlarge the small basal segments (Fig. 2M) it inherited from its lineage-5 ancestors. Yet it overcame the problem of tensile forces associated with increased drag on these fragile segments by covering them with a felt-like flexible collar of holdfast siphons (see illustrations in Taylor, 1950 and Hillis-Colinvaux, 1980).

The so-called pan-tropical species ( $H$. incrassata, H. discoidea, H. gracilis, and H. copiosa: Hillis-Colinvaux, 1980, 1988; Taylor, 1950) represent Atlantic and Indo-Pacific cognate pairs. Other phenotypically similar pairs (Atlantic $H$. goreauii and Indo-Pacific $H$. minima; Atlantic $H$. simulans and Indo-Pacific $H$. borneensis; Atlantic Halimeda monile and Indo-Pacific H. stuposa) are also genetically distantly related entities. Occurrence of these convergent taxa in similar habitats in disjunct ocean systems suggests that comparable selective pressures generated their phenotypic similarities. Yet, part of their likeness results from shared common ancestry because all pairs are encountered exclusively within lineages (Fig. 4). Cognates may differ in as yet unexplored traits of siphon anatomy and segment shape. In the case of Indo-Pacific H. copiosa, an old name is available because Colinvaux (1969) merged Indo-Pacific $H$. hederacea with Atlantic H. copiosa and therefore, we propose to re-establish provisionally $H$. hederacea as described by Colinvaux (1968).

Many authors have reported $H$. monile, H. simulans, and $H$. tuna from the Indo-Pacific (e.g., Hillis-Colinvaux, 1980, 1988; Taylor, 1950). Indeed, the occurrence of monophyletic $H$. opuntia in both oceans reveals the possibility of inter-oceanic dispersal. However, we suspect that $H$. monile and $H$. simulans are strictly Atlantic. These taxa can easily be confused with their Indo-Pacific look-alikes $H$. cylindracea and $H$. borneensis. Likewise, the description of $H$. tuna fits Indo-Pacific forms of $H$. discoidea with smallish secondary utricles (HillisColinvaux, 1980) that could drop below the taxonomic threshold value separating Atlantic $H$. discoidea and $H$. tuna. Claims of Atlantic species in the Indo-Pacific and vice versa need proof from sequence data, especially if these suspected intruders are members of cognate pairs or look-alikes. Phenotypic data alone are unsatisfactory because they are plastic and ridden with convergence. 


\subsection{Phylogeny and timing of gamete release}

Comparisons of the tree in Fig. 1 and gamete release intervals in Clifton and Clifton (1999) show that $H$. goreauii ( $-65 \mathrm{~min}$ relative to sunrise), H. opuntia $(-53.1 \pm 1.8), \quad H . \quad$ discoidea $(-51), \quad H . \quad$ simulans $(-20.2 \pm 1.4), H$. monile $(-16.8 \pm 1.9)$, H. tuna (-14.7), and $H$. incrassata $(+32.8 \pm 1.0)$ all avoid the release windows of the others, whether they are closely related or not. There must be a selective premium on avoiding other gamete release intervals because otherwise it remains difficult to explain why $H$. incrassata spawns well after sunrise thereby sustaining considerable losses of gametangia due to fish grazing (Clifton and Clifton, personal communication). One reason may be that they avoid hybridization (Clifton and Clifton, 1999), and therefore, are not completely reproductively isolated. If so, the extant diversity must be of relatively recent origin.

The Cliftons recorded gamete release intervals only in the San Blas region on the Atlantic coast of Panama. Knowledge of release intervals elsewhere in combination with population genetic data and cross-fertilization experiments could provide insights in patterns and mechanisms of speciation. Similar release intervals across sites throughout the tropical Atlantic would be indicative for a single, widely distributed population connected by gene flow whereas radically different release intervals among sites suggest patchiness and reproductive isolation.

\subsection{Phylogeny of the extant diversity and paleontology}

The phylogeny of Halimeda is particularly interesting because the genus possesses a fossil record. Such records are rare amongst marine macroalgae. Segment form and utricle shape associated with several Late Cretaceous Halimeda segments (Badve and Kundal, 1986; Badve and Nayak, 1983; Elliott, 1965; Morellet and Morellet, 1941; Schlagintweit and Ebli, 1998) resemble those encountered in lineages 1, 3, 4, and 5. Moreover, segments resembling those of extant $H$. opuntia have been reported from the Miocene (Bassoullet et al., 1983; Flügel, 1988; Morellet and Morellet, 1922). If one accepts these comparisons, the lineages originated anywhere before the Late Cretaceous and extant Halimeda species are living fossils like dasycladalean species (Olsen et al., 1994).

An Early Cretaceous origin of Halimeda as inferred from the fossil record contradicts a Miocene or younger age of the extant diversity as deduced from phylogeographic patterns (Fig. 4). For example, Miocene fossils believed to be $H$. opuntia conflict with a Pliocene age (ca. $3.1 \mathrm{Ma}$ ) of the Indo-Pacific clade that begot this species. Distinct gamete-release windows among Atlantic Halimeda species (Clifton and Clifton, 1999) also suggest recent diversification whereas hybridization would hardly be an issue for species of Miocene age. The observed scarcity of variation on SSU core sequences across the genus combined with elevated bryopsidalean SSU substitution rates (Zechman et al., 1999) support relatively recent diversification whereas Mesozoic cladogenesis should have generated more substantial SSU sequence difference among the lineages. We believe that Cretaceous and Early Tertiary Halimeda species predate the cenancestor of the extant diversity and that similarities between ancient fossil segments and extant ones results from iterative evolution of look-alikes in comparable habitats in different periods followed over and over again by their extinction. Examples of convergence among extant taxa already illustrate such repetition. Similar patterns have been recovered among taxa with an extensive fossil record such as ammonites (Newell, 1967) and Foraminifera (Cifelli, 1969).

The phylogeny presented here reveals only relationships among survivors; the fossil record could greatly refine this picture. Although convergence between extant and extinct diversity will continue to affect inferences on phylogenetic relatedness, distinct state differences among yet unexplored traits can support phylogenetic distinctness between groups of species in this common constituent of reef communities today as well as in the distant past.

\section{Acknowledgments}

This study was carried out at the Smithsonian Tropical Research Institute in Panama City, Republic of Panama. We are grateful to James Engman for his pioneering molecular work on Halimeda. Karen Arano, Inez Campbell, Rachel Collin, Olivier Dargent, Gabriela Etchelecu, Llewellya Hillis, Lisa Kirkendale, Frederick Leliaert, and Brian Wysor are thanked for specimens and Willem Prud'homme van Reine for use of herbarium samples from the National Herbarium, Leiden. Llewellya Hillis is also acknowledged for stimulating W.K. to study the phylogeny of Halimeda and for sharing part of her funding with him. S.T.R.I. is acknowledged for additional grants to W.K. We thank James Coyer, Gabriele Procaccini, and Giuseppe Zuccarello for discussion and suggestions for the manuscript improvement.

\section{References}

Avise, J.C., 2000. Phylogeography, The History and Formation of Species. Harvard University Press, Cambridge, MS.

Badve, R.M., Kundal, P., 1986. Marine calcareous algae from the Baratang Formation, Andaman Islands, India. Bull. Geol. Min. Met. Soc. India 54, 149-158. 
Badve, R.M., Nayak, K.K., 1983. Occurrence and significance of the algal genus Halimeda from Nimar Sandstone, Bagh Beds, Jhabua District, M.P. Biovigyanam 9, 137-148.

Bakker, F.T., Olsen, J.L., Stam, W.T., Van den Hoek, C., 1994. The Cladophora complex: new views based on $18 \mathrm{~S}$ rDNA gene sequences. Mol. Phylogen. Evol. 3, 365-382.

Bakker, F.T., Olsen, J.L., Stam, W.T., 1995a. Evolution of nuclear rDNA ITS sequences in the Cladophora albidalcericea clade (Chlorophyta). J. Mol. Evol. 40, 640-651.

Bakker, F.T., Stam, W.T., Olsen, J.L., 1995b. Global phylogeography in the cosmopolitan complex Cladophora vagabunda (Chlorophyta) based on nuclear rDNA ITS sequences. Eur. J. Phycol. 30, 197-208.

Ballantine, D.L., 1982. Halimeda hummii sp. nov., Halimeda cryptica v. acerifolia var. nov. (Caulerpales, Chlorophyta), and additional records of Halimeda species from Puerto Rico. J. Phycol. 18, 8691.

Barton, E.S., 1901. The genus Halimeda. Monographs of the Siboga Expedition, 60. Leiden.

Bassoullet, J.-P., Bernier, P., Genot, P., Poncet, J., Roux, A., 1983. Les algues Udoteacées du Paléozoique au Cénozoique. Bull. Cent. Rech. Explor. Prod. Elf-Aquitaine 7, 449-621.

Borowitzka, M.A., Larkum, A.D.W., 1977. Calcification in the green alga Halimeda.V. An ultrastructure study of the thallus development. J. Phycol. 13, 6-16.

Bowen, B.W., Bass, A.L., Rocha, L.A., Grant, W.S., Robertson, D.R., 2001. Phylogeography of the trumpetfish (Aulostomus spp.): ring species complex on a global scale. Evolution 55, 1029-1039.

Braga, J.C., Martin, J.M., Riding, R., 1996. Internal structure of segment reefs: Halimeda algal mounds in the Mediterranean Miocene. Geology 24, 35-38.

Bucur, I.I., 1994. Lower Cretaceous Halimedaceae and Gymnocodiaceae from southern Carpatians and Apuseni Mountains (Romania) and the systematic position of the Gymnocodiaceae. Beitr. Paläeontol. 19, 13-37.

Butler, R.W.H., McClelland, E., Jones, R.E., 1999. Calibrating the duration and timing of the Messinian salinity crisis in the Mediterranean: linked tectonoclimatic signals in thrust-top basins in Sicily. J. Geol. Soc. London 156, 827-835.

Cifelli, R., 1969. Radiation of Cenozoic planktonic Foraminifera. Syst. Zool. 18, 154-168.

Clifton, K.E., 1997. Mass spawning by green algae on coral reefs. Science 275, 1116-1118.

Clifton, K.E., Clifton, L.M., 1999. The phenology of sexual reproduction by green algae (Bryopsidales) on Caribbean coral reefs. J. Phycol. 35, 24-34.

Coates, A.G., Oblando, J.A., 1996. The geologic evolution of the Central American Isthmus. In: Jackson, J.B.C., Budd, A.F., Coates, A.G. (Eds.), Evolution and Environment in Tropical America. University of Chicago Press, Chicago, pp. 21-56.

Colborn, J., Crabtree, R.E., Shaklee, J.B., Philer, E., Bowen, B.W., 2001. The evolutionary enigma of bonefishes (Albula spp.): cryptic species and ancient separations in a globally-distributed shorefish. Evolution 55, 807-820.

Coleman, A.W., Mai, J.C., 1997. Ribosomal DNA ITS-1 and ITS-2 sequence comparison as a tool for predicting genetic relatedness. J. Mol. Evol. 45, 168-177.

Colinvaux, L.H., 1968. New species of Halimeda: a taxonomic reappraisal. J. Phycol. 4, 30-35.

Colinvaux, L.H., 1969. Halimeda copiosa and Halimeda hederacea. J. Phycol. 5, 88

Collado-Vides, L., DeWreede, R.E., Milligan, K.L.D., 1998. Biomechanical properties of Udotea (Halimedales, Chlorophyta) in a Mexican reef lagoon. Phycologia 37, 443-449.

Dong, M., Tseng, C.K., 1980. Studies on some marine green algae from the Xisha Islands, Guandong Province, China II. Stud. Mar. Sinica $17,1-10$.
Drew, E.A., 1993. Halimeda biomass, growth rates and sediment generation on reefs in the central Great Barrier Reef province. Coral Reefs 2, 101-110.

Drew, E.A., 1995. Diversity of the green algal genus Halimeda in the Chagos Archipelago, central Indian Ocean. Aquat. Bot. 52, 143150

Drew, E.A., Abel, K.M., 1988. Studies on Halimeda. II: reproduction, particularly the seasonality of gametangia formation, in a number of species from the Great Barrier Reef Province. Coral Reefs 6, 207-218.

Drew, E.A., Abel, K.M., 1990. Studies on Halimeda. III: a daily cycle of chloroplast migration within the segments. Bot. Mar. 33, 31-45.

Duffy, J.E., Hay, M.E., 1990. Seaweed adaptations to herbivory. Bioscience 40, 368-375.

Durand, C., Manuel, M., Boudouresque, C.F., Meinesz, A., Verlaque, M., LeParqo, Y., 2002. Molecular data suggest a hybrid origin for the invasive Caulerpa racemosa (Caulerpales, Chlorophyta) in the Mediterranean Sea. J. Evol. Biol. 15, 122-133.

Elliott, G.F., 1965. The interrelationships of some Cretaceous Codiaceae (calcareous algae). Palaeontology 8, 199-203.

Elliott, G.F., 1981. The Tethyan dispersal of some chlorophyte algae subsequent to the Palaeozoic. Palaeogeogr., Palaeoclimatol., Palaeoecol. 32, 341-358.

Famà, P., Olsen, J.L., Stam, W.T., Procaccini, G., 2000. High levels of intra- and inter-individual polymorphism in the rDNA ITS1 of Caulerpa racemosa (Chlorophyta). Eur. J. Phycol. 35, 349-356.

Flügel, E., 1988. Halimeda: paleontological record and palaeoenvironmental significance. Coral Reefs 6, 123-130.

Freile, D., Milliman, J.D., Hillis, L., 1995. Leeward bank margin Halimeda meadows and draperies and their sedimentary importance on the western Great Bahama Bank slope. Coral Reefs 14, $27-33$.

Gepp, E.S., 1904. The sporangia of Halimeda. J. Bot. London 42, 193 197.

Gilmartin, M., 1960. The ecological distribution of the deep water algae of Eniwetok. Ecology 41, 210-221.

Goloboff, P.A., 1993. Estimating character weights during tree search. Cladistics 9, 83-91.

Gori, P., 1979. Ultrastructure of the spermatozoid in Halimeda tuna (Chlorophyceae). Gamete Res. 2, 345-355.

Gould, S.J., Eldredge, N., 1977. Punctuated equilibria: the tempo and mode of evolution reconsidered. Paleobiology 3, 115-151.

Gutell, R.R., 1993. Collection of small subunit (16S- and 16S-like) ribosomal RNA structures. Nucleic Acids Res. 21, 3051-3054.

Hay, M.E., 1997. Calcified seaweeds on coral reefs: complex defenses, trophic relationships, and value as habitats. In: Proceedings of the 8th International Coral Reef Symposium, vol. 1, pp. 713-718.

Hay, M.E., Taylor, P.R., 1985. Competition between herbivorous fishes and urchins on Caribbean reefs. Oecologia 65, 591-598.

Hay, M.E., Colburn, T., Downing, D., 1983. Spatial and temporal patterns in herbivory on a Caribbean fringing reef: the effects on plant distribution. Oecologia 58, 299-308.

Hay, M.E., Paul, V.J., Lewis, S.M., Tucker, J., Trindell, R.N., 1988. Can tropical seaweeds reduce herbivory by growing at night? Diel patterns of growth, nitrogen content, herbivory, and chemical versus morphological defenses. Oecologia 75, 233-245.

Hay, M.E., Kappel, Q.E., Fenical, W., 1994. Synergisms in plant defenses against herbivores: interactions of chemistry, calcification, and plant quality. Ecology 75, 1714-1726.

Hershkovitz, M.A., Lewis, L.A., 1996. Deep-level diagnostic value of the rDNA-ITS region. Mol. Biol. Evol. 13, 1276-1295.

Hillis-Colinvaux, L., 1980. Ecology and taxonomy of Halimeda: primary producer of coral reefs. Adv. Mar. Biol. 17, 1-327.

Hillis-Colinvaux, L., 1986. Deep water populations of Halimeda in the economy of an atoll. Bull. Mar. Sci. 38, 155-169.

Hillis-Colinvaux, L., 1988. Calcareous green algae in the reefs of the Indian Ocean. Biol. Soc. Wash. Bull. 8, 14-18. 
Hillis, L.W., Engman, J.A., Kooistra, W.H.C.F., 1998. Morphological and molecular phylogenies of Halimeda (Chlorophyta, Bryopsidales) identify three evolutionary lineages. J. Phycol. 34, 669681.

Hillis, D.M., Huelsenbeck, J.P., 1992. Signal, noise, and reliability in molecular phylogenetic analyses. J. Hered. 83, 189-195.

Jorgensen, R.A., Cluster, P.D., 1988. Modes and tempos in the evolution of nuclear ribosomal DNA: new characters for evolutionary studies and new markers for genetic and population studies. Ann. Missouri Bot. Gard. 75, 1238-1247.

Jousson, O., Pawlowski, J., Zaninetti, L., Meinesz, A., Boudouresque, C.F., 1998. Molecular evidence for the aquarium origin of the green alga Caulerpa taxifolia introduced to the Mediterranean Sea. Mar. Ecol. Prog. Ser. 172, 275-280.

Kamura, S., 1966. On the sexual reproduction of two species of Halimeda (Chlorophyta). Bull. Arts Sci. Univ. Ryukyus, Math. Nat. Sci. 9, 302-313.

Kapraun, D.F., 1994. Cytophotometric estimation of nuclear DNA content in 13 species of the Caulerpales (Chlorophyta). Crypt. Bot. $4,410-418$.

Kooistra, W.H.C.F., in press. Molecular phylogenies of Udoteaceae (Bryopsidales, Chlorophyta) reveal non-monophyly for Udotea, Penicillus, and Chlorodesmis. Phycologia (in press).

Kooistra, W.H.C.F., Calderón, M., Hillis, L.W., 1999. Development of the extant diversity in Halimeda is linked to vicariant events. Hydrobiology 398/399, 39-45.

Lamouroux, J.V.F., 1812. Extrait d'un mémoire sur la classification des polypes coralligènes non entièrement pierreux. Nouveau Bulletin Scientifique de la Société Philomatique 3, 181-188.

Lessios, H.A., Kessing, B.D., Robertson, D.R., Paulay, G., 1999. Phylogeography of the pantropical sea urchin Eucidaris in relation to land barriers and ocean currents. Evolution 53, 806-817.

Lessios, H.A., Kessing, B.D., Pearse, J.S., 2001. Population structure and speciation in tropical seas: global phylogeography of the sea urchin Diadema. Evolution 55, 955-975.

Lewis, S.M., Wainwright, P.C., 1985. Herbivore abndance and grazing intensity on a Caribbean coral reef. J. Exp. Mar. Biol. Ecol. 87, 215-228.

Littler, D.S., Littler, M.M., 1990. Systematics of Udotea species (Bryopsidales, Chlorophyta) in the tropical western Atlantic. Phycologia 29, 206-252.

Littler, D.S., Littler, M.M., 1999. Blade abandonment/proliferation: a novel mechanism for rapid epiphyte control in marine macrophytes. Ecology 80, 1736-1746.

Littler, D.S., Littler, M.M., 2000. Caribbean Reef Plants: An Identification Guide to the Reef Plants of the Caribbean, Bahamas, Florida, and Gulf of Mexico. Offshore Graphics Inc., Washington DC.

Maddison, W.P., Maddison, D.R., 1997. MacClade: Analysis of Phylogeny and Character Evolution, Version 3.07. Sinauer, Sunderland, MA.

Mankiewicz, C., 1988. Occurrence and paleoecologic significance of Halimeda in late Miocene reefs, southeastern Spain. Coral Reefs 6, 271-279.

Mariani-Colombo, P., Orsenigo, M., 1977. Sea depth effects on the algal photosynthesis apparatus. II. An electron microscopic study on the photosynthetic apparatus of Halimeda tuna (Chlorophyta, Siphonales) at $-0.5 \mathrm{~m}$ and $-6.0 \mathrm{~m}$ sea depths. Phycologia $16,9-17$.

Matzura, E., Wennborg, A., 1996. RNAdraw: an integrated program for RNA secondary structure calculation and analysis under 32-bit Microsoft Windows. Comput. Appl. Biosci. 12, 247-249.

Mai, J.C., Coleman, A.W., 1997. The internal transcribed spacer 2 exhibits a common secondary structure in green algae and flowering plants. J. Mol. Evol. 44, 258-271.

Meinesz, A., 1980. Connaissances actuelles et contribution à l'étude de la reproduction et du cycle des Udotéacées (Caulerpales, Chlorophytes). Phycologia 19, 110-138.
Morellet, L., Morellet, J., 1922. Contribution à l'étude paléontologique du genre Halimeda Lamouroux. Bull. Soc. Géol. Fr. 22, 291296.

Morellet, L., Morellet, J., 1941. Études sur les algues calcaires de l'Éocène du Cotentin. Bull. Soc. Géol. Fr. 10, 201-206.

Müller, G.B., 1989. Ancestral patterns in bird wing development: a new look at Hampe's experiment. J. Evol. Biol. 3, 31-48.

Muss, A., Robertson, D.R., Stepien, C.A., Wirtz, P., Bowen, B.W, 2001. Phylogeography of the genus Ophioblennius: the role of ocean currents and geography in reef fish evolution.. Evolution 55, 561572.

Nakayama, T., Marin, B., Kranz, H.D., Surek, B., Huss, V.A.R., Inouye, I., Melkonian, 1998. The basal position of scaly green flagellates among the green algae(Chlorophyta) is revealed by analyses of nuclear-encoded SSU rRNA sequences. Protist 149, 367-380.

Neefs, J.M., Van de Peer, Y., De Rijk, P., Goris, A., De Wachter, R., 1991. Compilation of small ribosomal subunit RNA sequences. Nucleic Acids Res. 19, 1987-2015.

Newell, N.D., 1967. Revolutions in the history of life. Geol. Soc. Am. Special Papers 89, 63-91.

Nichols, R., 2001. Gene trees and species trees are not the same. Trends Ecol. Evol. 16, 358-364.

Noble, J.N., 1986. Halimeda magnidisca (Caulerpales, Chlorophyta), a new species from the Great Barrier Reef, Australia. Phycologia 25, 331-339.

Olsen, J.L., Stam, W.T., Berger, S., Menzel, D., 1994. 18S rDNA and evolution in the Dasycladales (Chlorophyta): modern living fossils. J. Phycol. 30, 729-744.

Olsen, J.L., Valero, M., Meusnier, I., Boele-Bos, S., Stam, W.T., 1998. Mediterranean Caulerpa taxifolia and C. mexicana (Chlorophyta) are not conspecific. J. Phycol. 34, 850-856.

Paul, V.J., 1997. Secondary metabolites and calcium carbonate as defenses of calcareous algae on coral reefs. In: Proceedings of the 8th International Coral Reef Symposium, 1, pp. 707-712.

Payri, C.E., 1988. Halimeda contribution to organic and inorganic production in a Tahitian reef system. Coral Reefs 6, 251-262.

Peters, A.F., van Oppen, M.J.H., Wiencke, C., Stam, W.T., Olsen, J.L, 1997. Phylogeny and historical ecology of the Desmarestiaceae (Phaeophyceae) support a southern hemisphere origin. J. Phycol. 33, 294-309.

Posada, D., Crandall, K.A., 1998. Modeltest: testing the model of DNA substitution. Bioinformatics 14, 817-818.

Prud'homme van Reine, W.F., Van den Hoek, C., 1988. Biogeography of Capeverdean seaweeds. Cour. Forsch. Inst. Senckenberg 105, 35-49.

Prud'homme van Reine, W.F., Van den Hoek, C., 1990. Biogeography of Macaronesian seaweeds, 1. Cour. Forsch. Inst. Senckenberg 107, $55-73$.

Rambaut, A., 1995. Se-Al, Sequence alignment program v1-d1. Department of Zoology, University of Oxford. Available from: http://evolve.zoo.ox.ac.uk/software/Se-Al/(andrew.rambaut@zoo.ox.ac.uk).

Riding, R., Braga, J.C., Martin, J.M., Sanchez-Almazo, I.M., 1998. Mediterranean Messinian Salinity Crisis: constraints from a coeval marginal basin, Sorbas, southeastern Spain. Mar. Geol. 146, 1-20.

Riseberg, L.H., Wendel, J.F., 1993. Introgression and its consequences. In: Harrison, R.G. (Ed.), Hybrid Zones and the Evolutionary Process. Oxford University Press, New York, pp. 70-109.

Roberts, H.H., Phipps, C.V., Effendi, L., 1987. Halimeda bioherms in the eastern Java Sea, Indonesia. Geology 15, 371-374.

Rögl, F., Steininger, F.F., 1984. Neogene Paratethys, Mediterranean and Indo-Pacific seaways. Implications for the paleobiogeography of marine and terestrial biotas. In: Brenchley, P.J. (Ed.), Fossils and Climate. Wiley, Chichester, pp. 171-200.

Sang, T., Crawford, D.J., Stuessy, T.F., 1995. Documentation of reticulate evolution in peonies (Paeonia) using internal transcribed 
spacer sequences of nuclear ribosomal DNA: implications for biogeography and concerted evolution. Proc. Natl. Acad. Sci. USA 92, 6813-6817.

Schlagintweit, F., Ebli, O., 1998. Halimeda paucimedullaris n. sp. and Oroseina pletzachensis n. sp., two new calcareous algae from the Upper Cretaceous of the Northern Calcareous Alps (Gosau Group, Austria), followed by remarks on Dissocladella? pyriformis Schlagintweit, 1991. Revue Paléobiol. Genève 17, 361-371.

Schluter, D., 2001. Ecology and the origin of species. Trends Ecol. Evol. 16, 372-380.

Shannon, L.V., 1985. The Benguela ecosystem. Part I. Evolution of the Benguela physical features and processes. Oceanogr. Mar. Bio. Annu. Rev. 23, 105-182.

Stark, L.M., Almodovar, L., Kraus, R.W., 1969. Factors affecting the rate of calcification in Halimeda opuntia (L.) Lamouroux and Halimeda discoidea Decaisne. J. Phycol. 4, 305-312.

Stearns, S.C., 1992. The Evolution of Life Histories. Oxford University Press, Oxford, GB.

Steneck, R.S., 1997. Crustose corallines, other algal functional groups, herbivores and sediments: complex interactions along reef productivity gradients. In: Proceedings of the 8th International Coral Reef Symposium, 1, pp. 695-700.

Swofford, D.L., 2001. PAUP* Phylogenetic Analysis Using Parsimony (*and other methods) Version 4.0b8. Sinauer Associates Inc., Sunderland, MA.

Taylor, W.R., 1950. Plants of Bikini and Other Northern Marshall Islands. University of Michigan Press, Ann Arbor, MI.

Taylor, W.R., 1960. Marine Algae of the Eastern Tropical and Subtropical Coasts of the Americas. University of Michigan, Ann Arbor, MI.

Tsuda, R.T., Kamura, S., 1991. Floristics and geographic distribution of Halimeda (Chlorophyta) in the Ryukyu Islands. Jpn. J. Phycol. 39, 57-76.

Tsuda, R.T., Wray, R.O., 1977. Bibliography of marine benthic algae in Micronesia. Micronesica 13, 85-120.

Valet, G., 1966. Sur une espèce rare et une nouvelle espèce d'Halimeda de Mélanésie. Rev. Gén. Bot. 73, 680-685.

Van den Hoek, C., 1987. The possible significance of long-range dispersal for the biogeography of seaweeds. Helgoländer Meeresunters. 41, 261-272.

Van den Hoek, C., Breeman, A.M., Bak, R.P.M., Van Buurt, G., 1978. The distribution of algae, corals and gorgonians in relation to depth, light attenuation, water movement and grazing pressure in the fringing coral reef of Curaçao, Netherlands Antilles. Aquat. Bot. 1, 269-308

Van den Hoek, C., Mann, D.G., Jahns, H.M., 1995. Algae: An Introduction to Phycology. Cambridge University Press, Cambridge, UK, 623 pp.

Van Oppen, M.J.H., Draisma, S.G.A., Olsen, J.L., Stam, W.T., 1995. Multiple trans-Arctic passages in the red alga Phycodrys rubens: evidence from nuclear rDNA ITS sequences. Mar. Biol. 123, 179 188 .

Van Valen, L., 1973. A new evolutionary law. Evol. Theory 1, 1-30.

Venkateswarlu, K., Nazar, R., 1991. A conserved core structure in the 18-25S rRNA intergenic region from Tobacco, Nicotiana rustica. Plant Mol. Biol. 17, 189-194.

Veron, J.E.N., 1995. Corals in Space and Time: The Biogeography and Evolution of the Scleractinia. Cornell University Press, Ithaca.

Vogel, S., 1996. Life in Moving Fluids: The Physical Biology of Flow, second ed. Princeton University Press, Princeton, NJ.

Vroom, P.S., Smith, C.M., Keeley, S.C., 1998. Cladistics of the Bryopsidales: a preliminary analysis. J. Phycol. 34, 351-360.

Walters, L.J., Smith, C.M., 1994. Rapid rhizoid production in Halimeda discoidea Decaisne (Chlorophyta, Caulerpales) fragments: a mechanism for survival after separation from adult thalli. J. Exp. Mar. Biol. Ecol. 175, 105-120.

Wanntorp, H.-E., Brooks, D.R., Nilsson, T., Nylin, S., Ronquist, F., Stearns, S.C., Wedell, N., 1990. Phylogenetic approaches in ecology. Oikos 57, 119-132.

Weaver, A.J., 1990. Ocean currents and climate. Nature 47, 432.

Wendel, J.F., Schnabel, A., Seelanan, T., 1995. Bidirectional interlocus concerted evolution following allopolyploid speciation in cotton (Gossypium). Proc. Natl. Acad. Sci. USA 92, 280-284.

White, T.J., Lee, S., Taylor, J., 1990. Amplification and direct sequencing of fungal ribosomal RNA genes for phylogenetics. In: Innis, M.A., Gelfland, D.H., Sninsky, J.J., White, T.J. (Eds.), PCR Protocols. Academic Press, New York, pp. 315-322.

Woelkerling, W.J., 1975. On the epibiontic and pelagic Chlorophyceae, Phaeophyceae, and Rhodophyceae of the western Sargasso Sea. Rhodora 77, 1-40.

Zechman, F.W., Kooistra, W.H.C.F., Olsen, J.L., Stam, W.T., 1999. Current perspectives on the phylogeny of ulvophycean green algae. In: Anon. (Eds.), Abstracts of the XVI International Botanical Congress, St. Louis, MI, p. 144. 